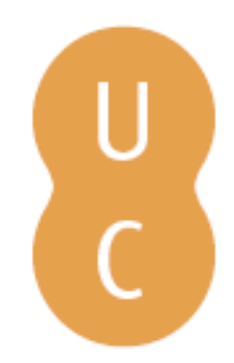

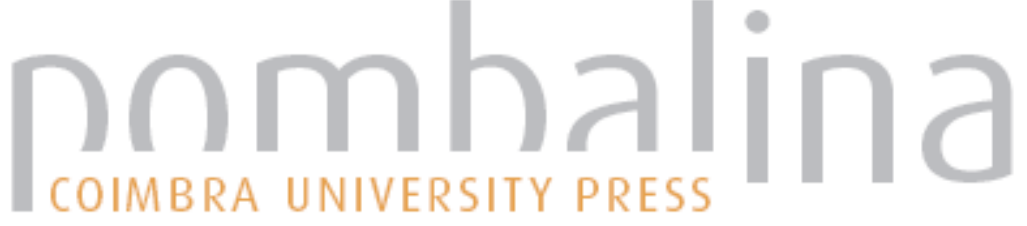

\section{Algunas notas sobre la Medea de Eurípides}

Autor(es): $\quad$ López Férez, Juan Antonio

Publicado por: Imprensa da Universidade de Coimbra

URL

persistente: URI:http://hdl.handle.net/10316.2/32294

DOI: $\quad$ DOI:http://dx.doi.org/10.14195/978-989-26-0472-5_2

Accessed : $\quad$ 26-Apr-2023 13:29:57

A navegação consulta e descarregamento dos títulos inseridos nas Bibliotecas Digitais UC Digitalis, UC Pombalina e UC Impactum, pressupõem a aceitação plena e sem reservas dos Termos e Condições de Uso destas Bibliotecas Digitais, disponíveis em https://digitalis.uc.pt/pt-pt/termos.

Conforme exposto nos referidos Termos e Condições de Uso, o descarregamento de títulos de acesso restrito requer uma licença válida de autorização devendo o utilizador aceder ao(s) documento(s) a partir de um endereço de IP da instituição detentora da supramencionada licença.

Ao utilizador é apenas permitido o descarregamento para uso pessoal, pelo que o emprego do(s) título(s) descarregado(s) para outro fim, designadamente comercial, carece de autorização do respetivo autor ou editor da obra.

Na medida em que todas as obras da UC Digitalis se encontram protegidas pelo Código do Direito de Autor e Direitos Conexos e demais legislação aplicável, toda a cópia, parcial ou total, deste documento, nos casos em que é legalmente admitida, deverá conter ou fazer-se acompanhar por este aviso.

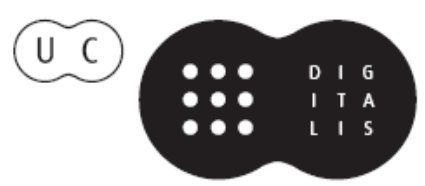


Emilio Suárez de la Torre

Maria do Céu Fialho

(Coordinadores)

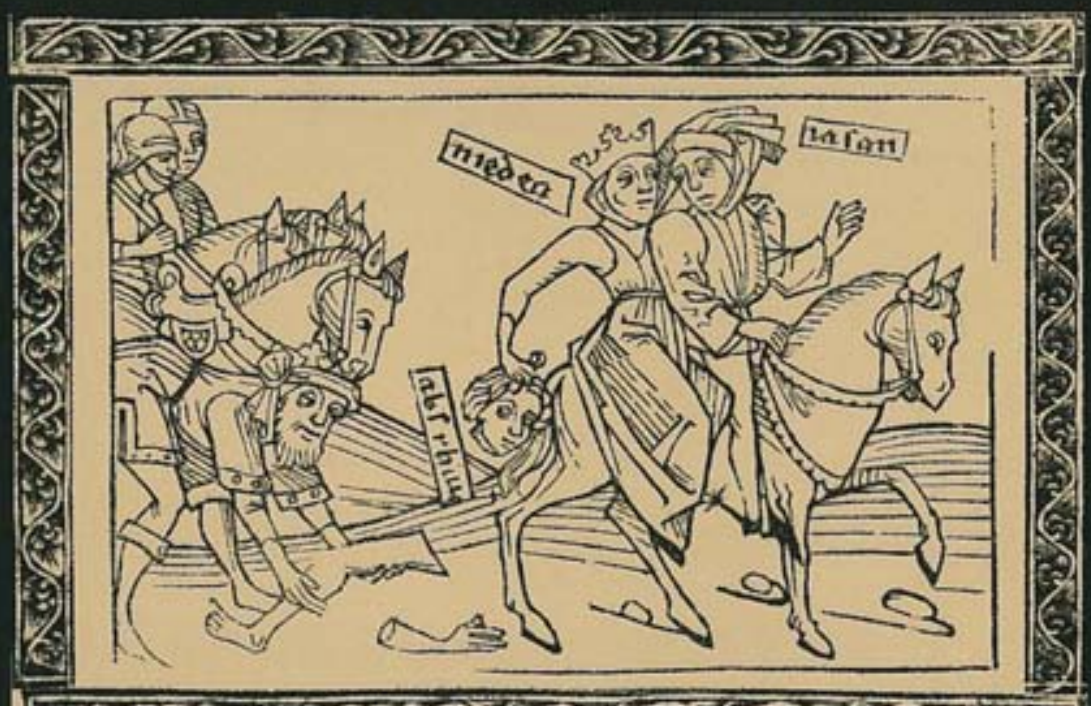

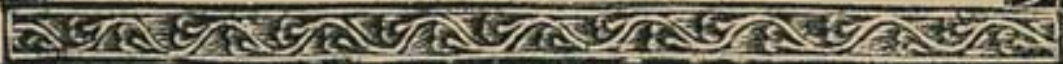

\section{BAJO EL SIGNO DE MEDEA}

\section{SOB O SIGNO DE MEDÉIA}




\section{Algunas notas sobre la Medea de Eurípides ${ }^{(1)}$}

JUAN ANTONIO LOPEZ FÉREZ

Universidad Nacional de Educación a Distancia (UNED), Madrid

La obra fue representada en el 431 a.C. El tema de Medea había sido tratado ya por nuestro autor dos veces: primero, en las Peliades, llevada a la escena en el 455 a.C, de la que nos han llegado dieciséis fragmentos, y donde la heroína logra engañar a las hijas de Pelias (usurpador del trono de Yolco, contra los legítimos derechos de Jasón), que descuartizan a su padre de modo infame, cuando pretendían rejuvenecerlo ${ }^{(2)} ; \mathrm{y}$, en segundo lugar, en $\mathrm{Egeo}^{(3)}$.

Los otros trágicos abordaron la leyenda de los Argonautas, pero no, en concreto, los hechos referentes a Medea. Por otro lado, los versos de la $\mathrm{Me}$ -

(1) Trabajo realizado dentro del Proyecto HUM2006-08548 de la Dirección General de Investigación. Ministerio de Educación y Ciencia.

(Aparecerá también, con algunas modificaciones, en Melanges offerts à Francois Jouan. Textes réunis par Danièle Auger et Jocelyne Peigney. Escribo estas líneas con amistad y agradecimiento hacia el Prof. Jouan. Conocía, desde hacía tiempo, su acribía filológica gracias a sus escritos, pero mi admiración aumentó desde el primer momento en que nos encontramos (Montpellier y Chantilly, 1986). Daré unas cuantas razones, entre muchas: su claridad de exposición; sus intervenciones, siempre pertinentes, llenas de tacto y agudeza, en los sucesivos coloquios y congresos en que hemos coincidido, varios de ellos en mi Universidad, a la que siempre acudió con mucho gusto; su trato fácil y amable; su interés y gusto por presentarme a amigos suyos, algunos de ellos figuras consagradas del helenismo europeo (Siracusa, 1987, donde se cimentó nuestra amistad con largas conversaciones sobre nuestra vida familiar y académica); el tuteo que me pidió casi desde los primeros momentos; en una palabra, su gran calidad intelectual y humana).

(2) Píndaro $(P .4 .251)$ y Ferecides (Fr. $105 F G H)$ indican que se trata de un relato antiguo. Pueden encontrarse más noticias en Apolodoro (1.9.27), Diodoro de Sicilia (4.50-53), Pausanias (8.11.2), Ovidio (Met. 7. 297-349), Higino (Fab. 24), etc.

(3) Conservamos una docena de fragmentos: del Egeo euripideo (Fr. 1-13), escrito en la década de 440, puede establecerse el argumento: Teseo llega a Atenas y tiene que luchar contra el toro de Maratón; aparece Medea. Había quizá una escena en que la maga proyecta el envenenamiento de Teseo. Al final, Egeo reconoce a su hijo y ordena que Medea marche al exilio. 
dea de Neofrón ${ }^{(4)}$ hay que considerarlos más bien imitación que precedente literario de nuestro autor.

$\mathrm{El}$ asunto mítico era conocido. Medea, hija de Eetes ${ }^{(5)}$ rey de la Cólquide, enamorada de Jasón, le presta ayuda valiosísima cuando éste llega al remoto país, en compañía de los Argonautas, para apoderarse del vellocino de oro. Tras un regreso lleno de peripecias y después de una estancia en Yolco, Jasón y Medea se refugiaron en Corinto.

Homero no habla de Medea, pero alude a Pelias, Eetes y los Argonautas ${ }^{(6)}$. Por su parte, Hesíodo, dentro de los descendientes de Helio, menciona a Medea y su unión con Jasón ${ }^{(7)}$. De otro lado, la relación de Medea con Corinto se remonta al siglo VIII, cuando Eumelo escribe las Corintiacas. En tal obra, Medea, mientras intentaba hacer inmortales a sus hijos, les dio muerte sin quererlo ${ }^{(8)}$. Sabemos por otras fuentes que Helio le regaló Corinto a Eetes ${ }^{(9)}$. Píndaro, en su Pitica cuarta, recoge la expedición de los Argonautas en busca del vellocino de oro ${ }^{(10)}$.

Eurípides selecciona un aspecto clave de la saga mítica. A saber, el momento en que Jasón viola el juramento dado a Medea en su día y se casa con Glauce, hija de Creonte, rey de Corinto. El héroe de otrora promete seguridad a los hijos habidos con Medea, pero a ella le niega amor y fidelidad.

Poco a poco dentro de la protagonista crece un odio terrible hacia el hombre que la ha traicionado. Valiéndose de sus hijos, logra, mediante engaños, acabar con Glauce y Creonte; $y$, para colmo de su venganza, para herir aún más a Jasón, da muerte a sus hijos con su propia mano. Finalmente, en un carro aéreo, tirado por serpientes aladas, huye hacia Atenas.

Desde el comienzo de la obra, Medea, herida en su orgullo, duda, medita, planea cuidadosamente la venganza; siente un odio cada vez mayor

(4) Euripides. Medea, ed. D.L. Page, pp. XXX-XXXVI; ed. Mastronarde, pp. 57-64.

(5) Eetes, Pasifae $y$ Circe eran hijos de Helio.

(6) De la nave Argo se habla en Od, 12. 69-72.

(7) Th. 961, 992 -1002. Se hace referencia a Yolco. Asimismo, se nos cuenta que la pareja tuvo un hijo (Medeo) que fue educado por el Centauro Quirón (Cf. Hecat., Fr. 286.2). En los fragmentos hesiódicos encontramos algunas noticias más o menos relacionadas con el mito de los Argonautas: cf. Fr. 40, 68, 151, 157, 241, 255 M.-W.

(8) Cf. Fr. 1-10 Bernabé. El mito se transforma para glorificar a Corinto.

(9) Paus. 2.3.10.

(10) P. 4. 9.57.218.250. Además, O. 13.53 y Fr. 172.7. Si en Píndaro, Jasón se muestra vigoroso y hábil, Eurípides nos presenta un personaje dependiente, en buena medida, de Medea, que le ayuda en momentos definitivos: por ejemplo, matando al dragón. 
contra Jasón; se manifiesta plena de dolor físico y moral; cuando se deja arrastrar por la cólera, se nos muestra como un ser bárbaro, asiático, salvaje, una fuerza de la naturaleza por encima del bien y del mal.

Mi propósito en esta ocasión es insistir en el léxico de algunos pasajes en que, a mi entender, el poeta nos da indicios sobre el modo de ser y pensar de la protagonista. Nuestro trágico, verdadero maestro en el uso de la lengua griega, selecciona cuidadosamente el vocabulario cuando, especialmente por boca de otros, nos habla del comportamiento y pensamientos de un personaje tan singular como la heroína de la pieza que examinamos.

1. En el prólogo la nodriza manifiesta un deseo imposible referido al pasado: habría querido, entre otras cosas, que su señora no hubiera navegado hacia las torres del país de Yolco:

...herida en su corazón por amor a Jasón,

$\mathrm{ni}$, tras convencer a las muchachas peliadas de que mataran

a su padre, habitaría esta tierra corintia

con su esposo e hijos... (11)

La idea esencial de la frase es el amor sentido por Medea hacia Jasón. Debemos entender el genitivo ('láøovos) como objetivo. Es la primera vez en la literatura griega en que, dependiendo de Ë $\rho \omega S$, tenemos una construcción tal, con la mención expresa de un nombre propio. Por lo demás, Eros (aquí dativus auctoris, es decir, el que realiza la acción) y el verbo pertinente (є̌ $\rho \mu \alpha \mathrm{L})$ se nos muestran con cierta frecuencia en la

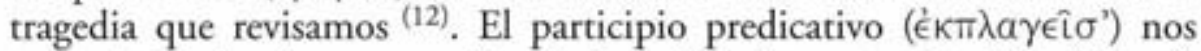
transmite, además, una noción de indudable importancia: Eros "hiere", "da un golpe" a la persona que resulta presa de él. Como indica el trágico en otros pasajes, el impulso amoroso no se ve como algo personal, voluntario y placentero, sino que, procedente de una divinidad, llega al mortal, y, luego, perfora y traspasa a su víctima ${ }^{(13)}$.

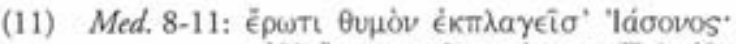

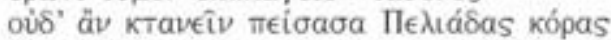

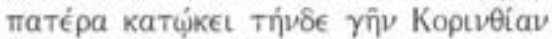

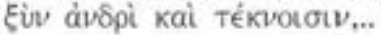

(Damos, con algunas variantes, el texto ofrecido por el $T L G$, que corresponde a la edición de J. Diggle).

(12) Respectivamente, Med. 330, 530, 627, 698, 714, 843; y 491, 688, 697, 974. En fecha anterior, o contemporánea, hallamos el genitivo objetivo (Thgn. 1350; S., Tr. 433; Hdt. 6.62.1), pero $\sin$ decir el nombre propio de la persona amada.

(13) Cf., por ejemplo, Hipp. 39 ("herida por los aguijones de Eros"), 392: "una vez que Eros me hirió..."; etc. 
Conviene subrayar la parte que ha resultado afectada por Eros, expresada mediante un acusativo de relación (también puede entenderse como

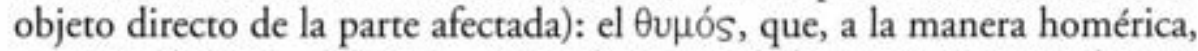
es tanto el deseo, el ánimo, como el asiento de los sentimientos, el corazón; la pieza que recorremos abunda en la presencia de tal elemento humano, físico y psíquico, a la vez ${ }^{(14)}$.

La nodriza apunta, de paso, a un hecho bien conocido en la tradición literaria: Medea persuadió a las hijas de Pelias a dar muerte a su padre, cuando pretendían devolverle la juventud, motivo que ocuparía buena parte del drama euripideo perdido Pelíades ${ }^{(15)}$. Asimismo sitúa la leyenda de la heroína en un punto concreto: su estancia en Corinto. El poeta, pues, limita de forma deliberada el espacio de la acción.

2. Otro detalle suministrado por la nodriza es el sufrimiento emocional de Medea:

Ahora hostil es todo, $y$ lo más querido padece enfermedad ${ }^{(16)}$.

En la oración nominal pura con que comienza el verso debemos referir la calidad de enemigo, hostil u odioso, al juicio y criterio de la protagonista: "le resulta odioso, le es odioso", aunque la expresión lingüística es deliberadamente ambigua. No obstante, el adjetivo é $\chi \theta$ pós, muy empleado en la pieza ${ }^{(17)}$, hasta tal punto que puede tomarse como uno de los hi-

(14) Med. $8,108,310,640,865,872,1056,1072,1152$. Los números en cursiva indican secuencias en que se alude a la protagonista; los subrayados los pronuncia ella, refiriéndose a sí misma.

(15) Cf. Fr. 601-616. En Med. 486, 504 hay referencias a esa saga mitica.

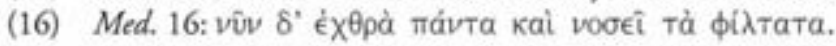

El neutro plural (тà фí $\lambda$ тата) para mencionar a una persona lo tenemos en S., Ph. 434. (Para la construcción sintáctica en nuestro trágico véase Tr. 27). No obstante, la última frase podría entenderse de otro modo, si aceptamos que el sujeto es Medea: "está enferma en lo más querido", entendiendo entonces el neutro plural como acusativo de relación.

Relevante, sin duda, es la enantiosis de los adjetivos que indican respectivamente la condición de enemigo y la de muy amigo, en la que insistiremos después.

(17) Lo encontramos en diecinueve secuencias: Med. 16, 95, 278, 374, 383, 507, Z34, $744,750,765,767,782,797,809,875,921,1050,1060,1341$. Salvo las dos que ponemos en cursiva, ambas pronunciadas por Jasón, todos los demás ejemplos apuntan a enemigos de la heroina; las subrayadas aparecen en boca de la misma: es de seńalar la sucesión 765-767782-797-809 todos en la misma resis, precisamente cuando Medea decide vengarse de todos los que, de un modo u otro, han herido su corazón.

Sólo otra tragedia, Heraclidas, con veintitrés apariciones, registra un número superior. A larga distancia quedan Fenicias e Hipólito, con once y nueve ejemplos, respectivamente.

(El adjetivo está bien registrado desde Homero (7), Esquilo (51) y Sófocles (47); es usado frecuentemente por nuestro poeta (118). Para el recuento de los ejemplos de éste último, tan- 
los conductores de la misma, nos hace ver que se está hablando concretamente de la protagonista.

Conviene entender Tà фí $\lambda \tau a \tau a$ como sujeto, "lo más querido", plural por singular: "el ser más querido". Jasón, pues, padece una enfermedad $^{(18)}$ especial: haber abandonado a la esposa y haber contraído nuevas nupcias.

3. Dentro asimismo del prólogo, la nodriza nos dice:

Medea, la desdichada que ha sufrido deshonra, menciona a gritos los juramentos, invoca la grandísima garantía de la mano derecha, $\mathrm{y}$ a los dioses pone por testigos de qué pago obtiene de Jasón. ${ }^{(19)}$

En estos versos se nos muestran varios conceptos esenciales: átı $\mu a ́ \zeta \omega$, "no darle a alguien la honra debida", es decir, "deshonrar", "ultrajar" (20); la mención de los juramentos (öpкoL) ${ }^{(21)}$ que en su día le diera Jasón a la

to en este caso como en el de los demás términos de que hablaré, sigo los datos obtenidos del $T L G$, pero descontando los textos repetidos (prọcedentes de ediciones diversas) y los correspondientes al espurio Reso).

[E] TLG, con todas sus limitaciones, una vez analizadas y comprobadas las cifras que ofrece en cada búsqueda, es un instrumento de primera importancia para examinar la evolución léxica y semántica desde Homero hasta los trágicos, y, asimismo, para sacar algunas conclusiones sobre cada uno de los tres grandes tragediógrafos. Mi intención, al manejarlo y presentar aquí los datos, es la de ayudar a entender mejor la Medea euripidea, $y$, posiblemente, la de impulsar ulteriores estudios].

(18) Med, sólo aquí registra el verbo voбeiv. De las dos apariciones del sustantivo correspondiente, destaca el v. 1364: "¡Oh hijos míos! ¡Cómo perecisteis por una enfermedad paterna!"

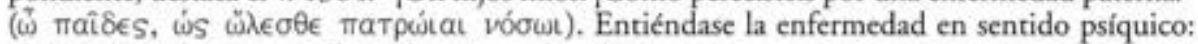
el desvarío o locura que lleva al varón a abandonar a esposa e hijos y contraer nuevo matrimonio. Para la pasión amorosa (concebida también al margen del matrimonio en el ejemplo que ponemos a continuación), véase Hipp. 765, donde el Coro, refiriéndose a Fedra, afirma:

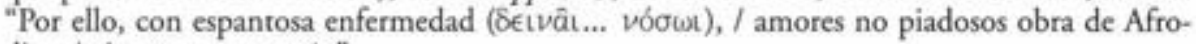
dita, / vio roto su corazón".

Si vóoos la encontramos en los poemas homéricos, vođéw no está registrado hasta el siglo V. Los trígicos lo usan de modo creciente: A. (4), S. (27), E. (72).

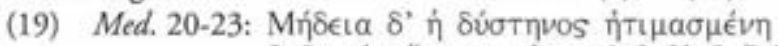

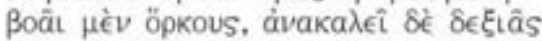

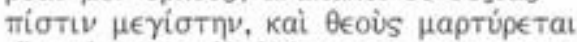

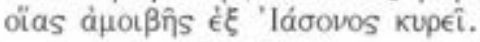

(20) Lo volvemos a encontrar en 33 y 1354; por su lado, el adjetivo ătıนos aparece en 438,696 ,

(21) Med. 161, 169, 439, 492, 735, 754. Las cursivas corresponden a la protagonista; los dos últimos citados se dan en su diálogo con Egeo. Además, se nos habla de Temis ópкía (209), es decir, protectora del juramento. Hipólito, con nueve apariciones del sustantivo, es la obra euripidea que más lo registra. 
heroína, a saber, la firme promesa de hacerla su esposa; la garantía ${ }^{(22)} \mathrm{da}-$ da con la mano derecha $\left(\delta \in \xi\right.$ เâs) ${ }^{(23)}$; poner a los dioses por testigos ( $\mu a \rho-$ TúpeTal) ${ }^{(24)}$ del pago recibido. La heroína, pues, se siente ultrajada tanto en el terreno humano (falta de honra), como en el plano divino (Jasón le había jurado, por los dioses, casarse con ella).

\section{Siguiendo con el prólogo, leemos lo siguiente:}

Yace sin comer, entregando su cuerpo a los dolores, consume todo su tiempo con lágrimas,

una vez que notó sufrir injusticia por obra de su esposo,

y ni alza los ojos ni aparta de tierra

su rostro. ${ }^{(25)}$

Desde la Odisea permanecer sin comer es indicio de problema profundo, de trastorno psíquico ${ }^{(26)}$. Tras saber que su marido cometía injusticia ${ }^{(27)}$ contra ella, la heroína muestra varios rasgos evidentes de profundo

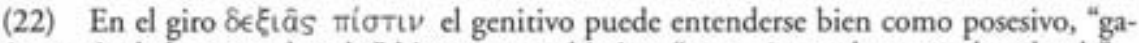
rantía propia de la mano derecha" bien como subjetivo, "garantía que la mano derecha da".

(23) Como Mastronarde recoge en nota oportuna, en una boda normal unen la mano derecha, en señal de garantía, tanto el novio como el padre de la novia o el representante legal de la misma (pero no la propia novia). Medea, en cambio, le dio la mano derecha a su prometido.

Véanse, además, 496, 899 (donde la heroína les pide a sus hijos que tomen la de Jasón), 1070 (se la pide a sus hijos), 1365 (en boca de Jasón). Fuera de nuestra pieza, es $L A$ la que más veces emplea el término que examinamos: ocho veces; conviene destacar 831 , donde Clitemnestra le pide a Aquiles que le ponga la mano derecha en la suya (pues, según pensaba ella, era el prometido de su hija).

(24) Es revelador que las otras dos veces en que el verbo está registrado en esta pieza, 619 y 1410, aparezca en boca de Jasón, cuando, respectivamente, quiere poner a las divinidades por testigos de su deseo de socorrer a Medea y a sus hijos, y de que ésta, tras dar muerte a sus retoños, no le consiente tocarlos ni sepultar sus cadáveres.

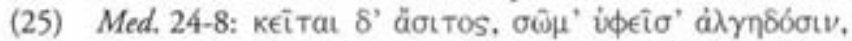

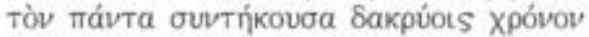

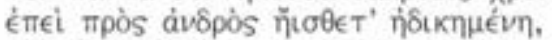

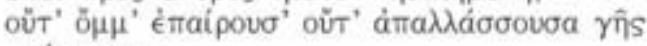

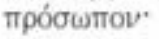

(26) Penélope, Od. 4.789, permanece sin comer, sin probar comida ni bebida, pensando si Telémaco escaparía de la muerte o moríría a manos de los pretendientes. El sofocleo Áyax, Ai. 324, no toma comida ni bebida cuando se da cuenta de lo que ha hecho. Los escritos hipocráticos nos ofrecen algunos ejemplos de sumo interés: así, cuando leemos que, en Tasos, "una mujer de carácter triste, a consecuencia de una preocupación con motivo, sin

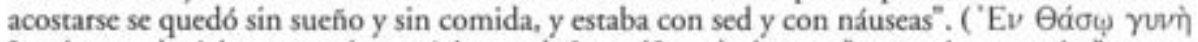

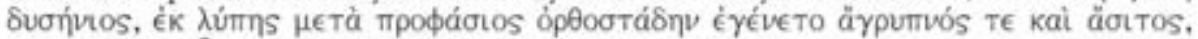

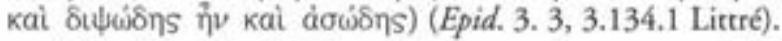

(27) El verbo áôkéw aparece por primera vez en el Himno homérico A Deméter (367) y en Teognis (1283). En los trígicos, si partimos de los empleos del tema ástK-, Esquilo pre- 
malestar psíquico: la entrega corporal al dolor ${ }^{(28)}$, el llanto ${ }^{(29)}$ incesante, la cabeza baja y la mirada fija hacia el suelo ${ }^{(30)}$.

5. Casi al final del prólogo la nodriza ofrece más señales sobre su señora:

Horror tiene de sus hijos y no disfruta al contemplarlos.

Temo que urda algo raro.

Violento es su corazón y no tolerará pasarlo

mal. A ésta yo la conozco, y temo que

afilado puñal se atraviese por el hígado,

tras entrar en silencio a su morada, donde está extendido el lecho,

o que al rey y al que se ha casado los mate,

y luego consiga desgracia mayor.

Terrible es. Si uno provoca su odio,

hermosa victoria no obtendrá. (31)

senta en cinco ocasiones el verbo, de doce usos de dicho tema; Sófocles, dos de ocho; Euripides, veintisiete de ciento tres. Concretamente en Medea, leemos el verbo en 165 y 692 (más tres veces el adjetivo ăర(xos). Aún más destaca Eurípides en el uso del tema provisto de aumento: ทंठtK-, pues Sófocles lo registra sólo en un ejemplo, mientras que nuestro trágico lo tiene en veintiséis ocasiones. Medea recoge el perfecto medio-pasivo en 26, 221, 265 y 314. Tal forma la hallamos otras seis veces en nuestro tragediógrafo, que resulta ser el único de los tres grandes trágicos que la recoge.

(28) El sustantivo $\dot{\alpha} \lambda \gamma \eta \delta \hat{\omega} v$-óvos, "dolor, sufrimiento físico o moral", aparece por primera vez en nuestro trágico: seis veces; tres de ellas en Medea, tanto con valor físico (v. 1031, referido a los partos), como moral (aquí y en v. 56, donde lo encontramos en boca de la nodriza). Posteriormente lo ofrece, por ejemplo, Sófocles, sólo una vez: OC 514. Señalemos, asimismo, las trece secuencias recogidas en el Corpus Hippocraticum y las treinta de las obras platónicas.

(29) La importancia de las lágrimas en Eurípides puede deducirse del uso de términos relacionado con el tema $\delta a \kappa p v-: 197$ ejemplos, frente a 46 en Esquilo y 37 en Sófocles. Medea (10) ocupa un lugar intermedio entre las piezas euripideas, en las que destacan $\mathrm{Hel}$. (26), $L A$ y $O r$. (21 en cada una de ellas).

(30) Los dos últimos indicios muestran que la heroina no quiere verse en el compromiso de hablar con los demás; por eso mantiene la mirada fija en el suelo.

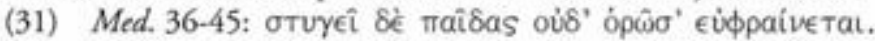

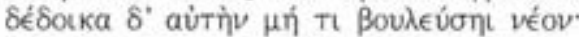

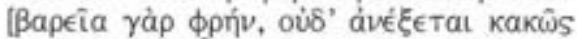

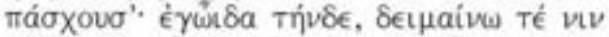

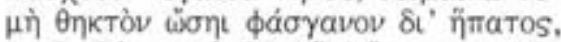

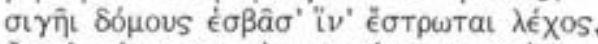

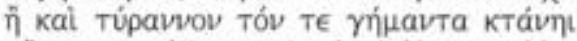

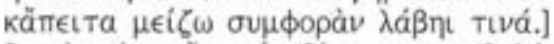

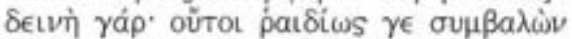

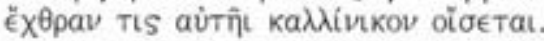


Lo peor que se puede decir de una madre es que odia a sus retońos y que no goza al verlos: Eurípides en un innovador en la expresión de tal

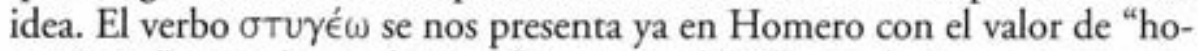
rrorizarse" ante algo o alguien, "sentir repulsión" por alguien, con un sentido físico más fuerte que el sinónimo $\mu$ té́w. También es homérico el

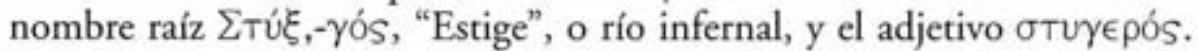
Los trágicos emplean tanto esos términos como otros nuevos del tema

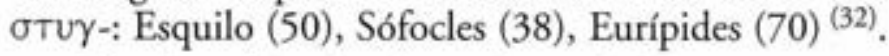

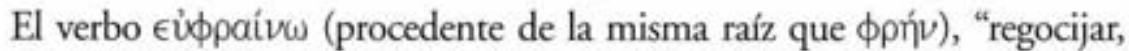
alegrar", presente desde Homero (3), es utilizado asimismo por los tres trágicos: Esquilo y Sófocles, con un empleo en cada uno, y Eurípides (5). La voz media, también homérica ${ }^{(33)}$, no vuelve a encontrarse hasta nuestro poeta ${ }^{(34)}$.

En los versos que hemos seleccionado leemos tres formas derivadas

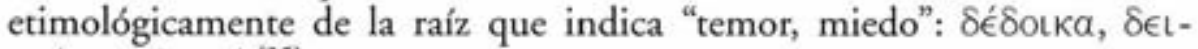
$\mu a i \nu \omega$ y $\delta \in \iota \nu \eta^{(35)}$.

(32) Medea, con nueve apariciones, es la pieza euripidea más rica en el uso de tal tema: cinco veces el verbo $(36,221,463,1374)$, cuatro, el adjetivo ya visto $(193,113,147,994)$, y una, el adjetivo orúyıos, derivado de ¿TúE (195).

(33) Od. 2.311.

(34) En dos ocasiones: aquí y en Alc. 323.

(35) No puedo detenerme todo lo necesario en el comentario de estos tres términos, cuya acumulación en tan pocos versos ha hecho sospechar a algunos críticos en afiadidos e interpolaciones. Muy útil es la aportación de F. Jouan, "Qui a peur de Médée", en Médée et la violence..., 87-97.

Los vv. 40-1 aparecen repetidos en 379-80. Diggle, siguiendo a Dindorf $y$ a otros editores, secluye los vv. 38-43. Se solucionan, con ello, algunas dificultades, pero, al mismo tiempo, se crean otras. Son puntos importantes en que no voy a entrar.

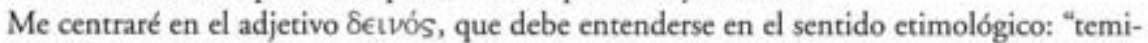
ble, que da miedo". En la Iliada, por ejemplo, es el calificativo de Apolo (4.514), Atenea (6.380) y la Estige (2.755); en la Odisea, de Circe $(10.136 ; 11.8 ; 12.150$; etc. Recordemos que era tía de Medea), Caribdis $(12.430 ; 23.327)$, etc. En Sófocles, de Palas (Ai. 952), Ares (OC 1065), Eris (Ph. 798), el Deseo sexual (Tr. 476: Himeros), etc. En la propia Medea, que estamos revisando, sirve para adjetivar a Cipris (Med. 642).

El término es bastante utilizado en nuestro poeta: por número de apariciones, sobresalen Or. (19), y Med,- IT (18 cada una). Nuestra tragedia lo presenta, concretamente, en vv. 44, $119,198,356,403,520,585,642,658,859,1121,1167,1184,1202,1214,1243,1290$, 1294); se refiere directamente al modo de ser o a las acciones y actitudes relacionadas con la protagonista, en 44, 356 (en boca de Creonte), 403 (la propia heroina se da ánimos para encaminarse al momento horrible), 658 (el Coro alude a las muy terribles desdichas del personaje central), 859 (el Coro habla de la espantosa audacia que Medea se dispone a cometer), 1121 (el Mensajero califica el espantoso crimen cometido contra la ley: la muerte de la recién casada y de su padre, Creonte), 1243 (Medea apunta al mal terrible, pero necesario, que se dispone a realizar: la muerte de sus hijos), 1294 (Jasón lo atribuye al asesinato de sus hijos).

Siguiendo los datos del TLG, respecto a la presencia de $\delta \in t V$ - en los trágicos, tenemos: A. (43), S. (128), E. (262). 
La nodriza teme que Medea "maquine algo nuevo", expresión sintáctica en que el adjetivo véov, que constituye el acusativo interno, está cargado de tintes negativos. Es un giro que tenemos en los otros trágicos ${ }^{(36)}$. La acción de deliberar y tomar decisiones tiene especial importancia en la obra que revisamos ${ }^{(37)}$.

El modo de ser y actuar de la heroína recibe una pincelada ilustradora con la frase "violento es su ánimo". El sustantivo $\phi \rho \eta ́ v-\phi \rho \in v o ́ s{ }^{(38)}$ ocupa un lugar importante en la pieza que nos ocupa ${ }^{(39)}$. Desde Homero en ese órgano anímico, no siempre bien localizado ${ }^{(40)}$, se sitúan varios elementos intelectuales, por oposición a los impulsos irracionales propios del $\theta u \mu o ́ s$.

La nodriza advierte del peligro que corre quien suscite el odio ${ }^{(41)} \mathrm{de}$ su señora: pues no cantará victoria ${ }^{(42)}$ sobre ella.

(36) Cf., A., Supp. 1016; S., Ph. 1229; etc.

(37) Quince formas con el tema ßouגeu- están registradas en Medea, más que en ninguna otra tragedia euripidea: seis secuencias del verbo y nueve del sustantivo abstracto (éste siempre en plural y al final del verso). Pensemos en $M e d$. 402, donde la heroína, dirigiéndo-

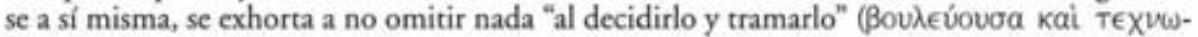

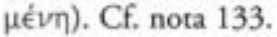

(38) Hom. (341), A. (132), S. (76), E. (168).

(39) Con trece usos, es la segunda obra euripidea en número de apariciones (la primera es Hipólito: 34). El término se refiere concretamente a la protagonista en vv. 38, 104, 143 . $177,316,599,856,1052,1373$. Recibe algunos calificativos: "violento, impetuoso, grave"

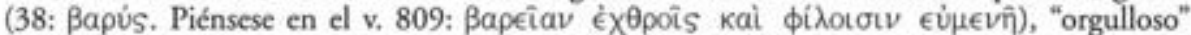

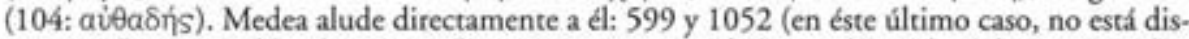

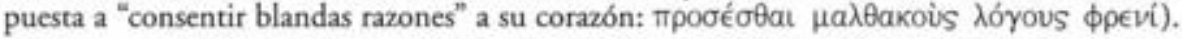

(40) "Diafragma", "entrañas", "corazón". En general, como órgano anatómico, se le sitúa en la parte superior del cuerpo. Pero, junto a eso, es también el asiento de las pasiones: "espíritu". El plural, sobre todo, suele traducirse en espafiol por "mientes", en la medida que resulta ser el asiento del pensamiento y la voluntad. En el pasaje que revisamos hemos traducido por "corazón", pero también podría ser "espíritu", "ánimo". En cada ocasión hay que conjeturar si prevalece lo físico o lo psíquico, según las connotaciones recibidas y el contexto.

(41) El sustantivo ě $\chi \theta \rho a$, "hostilidad, odio, aversión", lo tenemos a partir de Esquilo y Píndaro (Para é X $\theta$ pós cf. nota 48). En Eurípides está registrado en doce ocasiones. Cf. Med. 897, cuando la heroína les habla de este modo a sus hijos:

$$
\text { "...y apartaos a la vez }
$$

del odio anterior hacia los amigos, en unión de vuestra madre"

$$
\text { ... кai } \delta\left\llcorner a \lambda \lambda a ́ x \theta \eta \theta^{\prime} \text { ã } \mu a\right.
$$

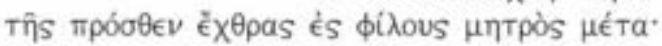

(42) Kaגínkov puede funcionar como sustantivo, sin artículo, uso raro, pero no imposible (así lo interpreto, siguiendo a varios estudiosos), o ser un adjetivo que acompañaría al objeto interno, elíptico, del verbo "cantar": " hermosa melodía de victoria". El término aparece en Píndaro, tanto en su función adjetival (7) como en la de sustantivo (1); entre los trágicos el único que lo registra con seguridad es nuestro autor que muestra especial predilección por el vocablo (31): destacan $H F(8)$ y $\mathrm{Ph}$. (7). 
6. La nodriza dialoga con el anciano pedagogo, encargado de acompañar a los hijos de Jasón y Medea:

Y tú, lo más posible, a éstos manténlos aislados,

y no los acerques a su madre abatida.

Ya la he visto dirigiendo mirada de toro

contra éstos, como si intentara algo. No cesará

en su cólera, ¡bien lo sé!, hasta que ataque a alguien.

¡Así les haga algo a sus enemigos, que no a los amigos! (43)

La heroína, pues, con la cabeza baja, en silencio, sin ganas de mirar a nadie, sin levantar los ojos para no verse en la necesidad de entablar conversación con nadie, se encuentra en una situación de profundo desánimo; en una palabra, está dominada por la $\delta v \sigma \theta v \mu i a^{(44)}$ : "tristeza, abatimiento, falta de ánimo".

El abatimiento no impide, con todo, que la protagonista, en otros momentos, mire a sus hijos con ojos fieros. La imagen de la mirada propia de un toro la tenemos en otros autores algo posteriores ${ }^{(45)}$.

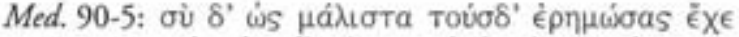

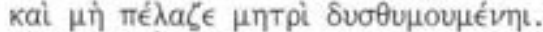

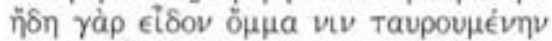

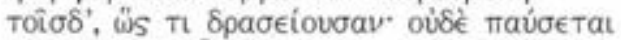

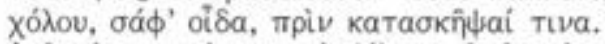

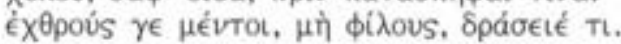

(44) Cf. Med. 691, donde Egeo le pregunta: "¿Qué afirmas? Cuéntame claramente tu

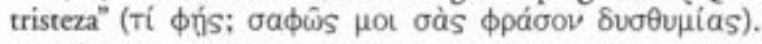

El sustantivo $\delta$ vovuria lo registra la tragedia en un fragmento sofocleo y en cuatro pasajes euripideos. También lo tenemos en siete textos hipocráticos, en cuatro de los cuales se nos

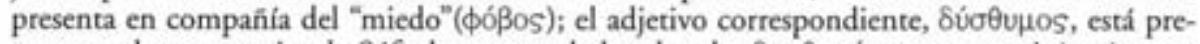

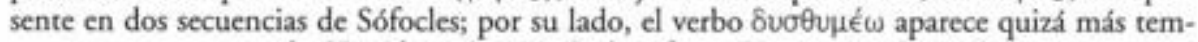
prano, pues, aparte de Heródoto (8.100.3), lo ofrece Demócrito (B 286.2): éste recoge, precisamente, la voz media, como sucede en el pasaje que estamos revisando; a su vez, los escritos hipocráticos contienen asimismo una aparición del mismo; Eurípides lo utiliza en dos ocasiones.

En los Aforismos hipocráticos (6.23) leemos: "Si el miedo o la tristeza duran mucho tiem-

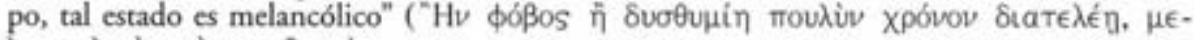

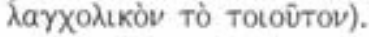

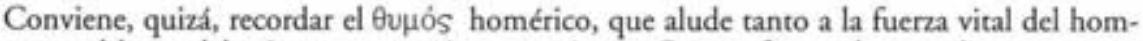
bre como al lugar del mismo en que tiene su asiento. Como afirman los estudiosos, no está clara la relación etimológica con el latín fumus.

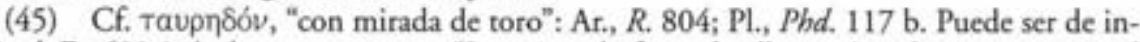
terés el Fr. 689.3-4, de nuestro autor: "Los ojos, de fuego los llenas, / cual toro que mira el ataque de un león". 
La mención de la cólera ${ }^{(46)}$ de Medea le permite a la nodriza referirse a su carácter inflexible, pues sabe bien ${ }^{(47)}$ que no cesará hasta que su rabia descargue ${ }^{(48)}$ sobre alguien.

Una vez más se nos presenta la oposición "enemigo/amigo" de la que algo hemos de decir ${ }^{(49)}$.

El giro sintáctico del texto ofrecido tiene sus dificultades; conviene entender el participio como predicativo del complemento directo (vtv); no está claro si el sentido del participio es medio ("convirtiéndose en toro", en donde cabría hablar de la intervención del sujeto (Me-

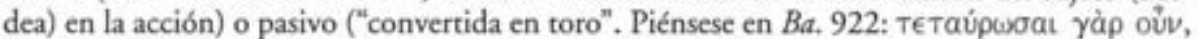

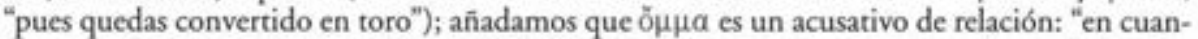
to a la mirada" y el déíctico Toî̋ $\delta$ ' (referido a los hijos, presentes en escena) un dativus incommodi: "en perjuicio de éstos".

Sobre la "mirada maléfica" de Medea, nota esencial para entenderla como "chivo expiatorio", véase A. Moreau, Médée et la violence, ...p. 104.

(46) Desde Homero contamos con Xó̉os, "bilis, cólera, resentimiento"; a partir de Arquíloco aparece Xoגń, que terminará por imponerse en los médicos hipocráticos para aludir a la bilis.

En los trágicos prevalece el primer sustantivo: A. (6-0), S. (5-1), E. (14-2). Concretamente, en Medea lo encontramos en vv. 94, 99, 172, 590, 898, 1150, 1266. Es decir, la mitad de ejemplos euripideos del sustantivo indicado se nos presenta en la obra que estamos revisando. Además, salvo en 1150, donde apunta al enfado de la recién casada por la llegada de los hijos de Jasón, los demás se refieren a la protagonista: su estado de ánimo es subrayado varias veces

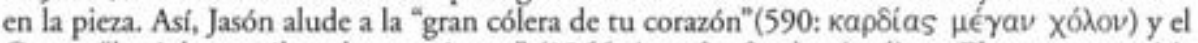

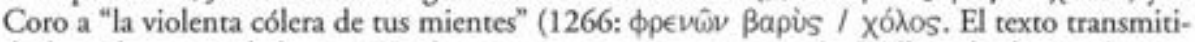
do ha sido enmendado por Diggle, que acepta una conjetura de Seidler: el adjetivo $\phi \rho \in v o-$ ßapŕs, no recogido en los diccionarios; fuera de esa conjetura, tampoco lo ofrece el TLG). Por otra parte, en v. 898, si nos atenemos al término orrov6aí ("tregua", propiamente, "libación" que se hace a los dioses como garantía del cese de hostilidades) que sale de labios de Medea, su cólera contra Jasón habría sido como una batalla, una guerra interior, pues, cuando, aparentando reconciliarse con él, llama a sus hijos para que abracen al padre, afirma: "Treguas hay en-

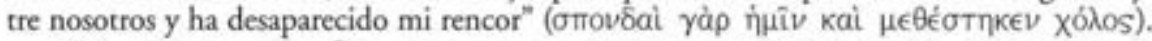

(47) El giro $\sigma a \phi^{\prime}$ oi $\delta a$ no es muy usado: Homero (4), Esquilo (4), Sófocles (1), Euripides (5), etc. Contiene el adverbio arcaico đáфa (que es más antiguo que el adjetivo corres-

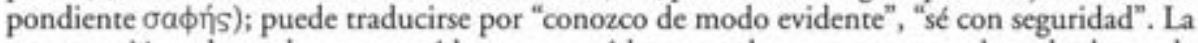
construcción subraya lo que es evidente, conocido por todos; en este caso, el modo de ser de Medea. Puede entenderse, pues, que la heroína había dado cumplidas muestras de su carácter colérico, inflexible y vengativo a lo largo de su existencia.

(48) El verbo катабкт́тт ha planteado varios problemas, pues el texto transmitido lo presenta con complemento directo en esta ocasión, cuando su régimen normal es acusativo con preposición ( $\epsilon i s)$ o un dativo que recibe las consecuencias de la acción verbal. El sujeto del infinitivo sería la cólera que atacaría a alguien, o descargaría su fuerza contra el mismo.

El escoliasta interpreta tal verbo como sinónimo de "herir", y lo explica a partir de golpear con el rayo, fulminar.

(49) Con respecto a Medea, recordemos lo dicho sobre el adjetivo éx日pós en nota 17. A propósito del mismo, los estudiosos apoyan una etimología interesante, a saber, lo ponen en relación con el hombre extranjero, el que viene de fuera del país.

Lo de hacer algo (en sentido eufemístico, desde luego, entiéndase algo así como "perjudicar, dañar") a los enemigos, no a los amigos, es una idea recurrente en toda la literatura grie- 
7. En una escena anapéstica la nodriza advierte a los nińos el modo de ser de su madre, pidiéndoles que no se le acerquen y eviten su cólera. Así dice tras los lamentos de la protagonista que desea la muerte:

Esto es aquello que decía, queridos niños. Vuestra madre mueve su corazón, mueve su cólera.

Marchad más de prisa dentro de la morada;

no os acerquéis al alcance de su mirada

ni os aproximéis; mas precaveos

de su carácter salvaje y la odiosa naturaleza

de su corazón orgulloso.

¡Idos pues! ¡Marchaos, a toda prisa, adentro!

Claro resulta; en sus comienzos se alza

nube de sollozos: la prenderá pronto

con mayor furor. ¿Qué hará

un ser de grandes entrañas, difícil de refrenar,

al ser mordido por las desdichas? ${ }^{(50)}$

ga. En nuestro poeta tenemos algunos ejemplos, de los que recojo dos: Fr. 1091: "de norma es

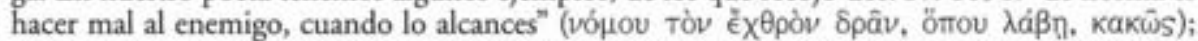

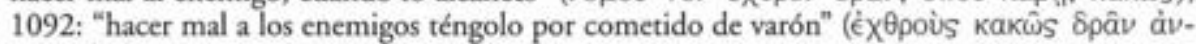

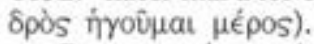

Respecto a la oposición antitética amigo/enemigo en nuestra pieza, es significativo cómo se autodefine la heroína: 809 , "terrible para mis enemigos, benévola con mis amigos" ( $\mathrm{Ba}$ -

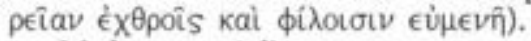

Medea no está dispuesta a que sus enemigos (Jasón, la joven esposa y Creonte) se rían de ella $(383,797)$; confia en que los tales paguen la pena debida $(767)$; no acepta la idea de dejarlos sin castigo (1050); no acepta dejar en Corinto a sus hijos para que los enemigos cometan ultrajes contra ellos $(782,1060)$.

Por su lado, no puedo extenderme en este lugar sobre el adjetivo $\phi(\lambda \circ \mathrm{S}$, que requiere un examen detenido. Si contamos los datos totales proporcionados por el TLG del tema $\phi \mathrm{t} \lambda$ - tenemos: Hom. (884), A. (310), S. (298), E. (1023): descontado ya el Reso, pero habría que sustraer varios ejemplos repetidos). Destaca, pues, nuestro trágico sobre los otros dos, aunque tengamos en cuenta el mayor número de obras que nos ha legado.

Si nos ceñimos a Medea, resulta ser la tercera en número de usos (63), sólo por detrás de Or. (76) y $H F(65)$. De esos sesenta y tres ejemplos, cincuenta y siete corresponden estrictamente al adjetivo que revisamos.

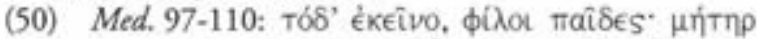

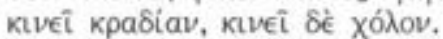

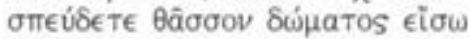

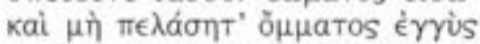

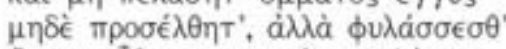

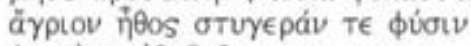

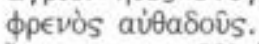
โTe vvv, X

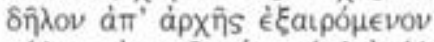

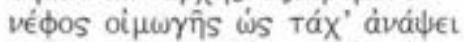

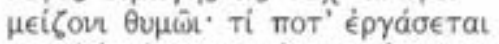

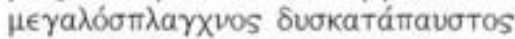


Es una de las primeras secuencias en que un ser humano actúa directamente sobre su corazón ${ }^{(51)}$. No deja de tener relevancia la anáfora: "mueve... mueve".

Un estudio especial merecería la orden que la nodriza les da a los niños: no acercarse a su madre, no ponerse, ni siquiera, al alcance de su vista; teme, en realidad, por la integridad física de los menores. No conozco precedentes de admonición tal en la literatura griega anterior a nuestra pieza.

La nodriza les pide otra cosa a los nin̄os: "que se pongan en guardia", a la defensiva, del carácter salvaje de su madre. El sustantivo $\eta \theta^{\dagger}$ oS $^{(52)}$, ya homérico, adquiere desde Hesíodo ${ }^{(53)}$ una connotación especial al pasar al campo del comportamiento y modo de ser, del carácter, en suma. Es un aspecto bien estudiado por los especialistas. Llama la atención el adjetivo "salvaje" (54) aplicado al modo de ser ${ }^{(55)}$.

\section{$\psi$}

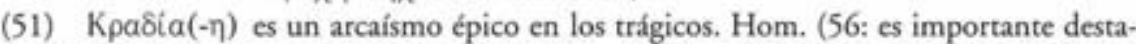

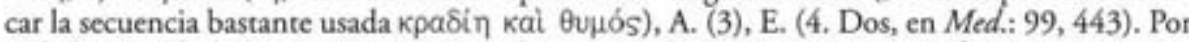
su lado, $\operatorname{kap\delta i} i(-\eta)$ apenas presente en los poemas homéricos (3), es más frecuente en tragedia: A. (28), E. (33. En Med. seis apariciones: 245, 590, 858, 1042, 1242, 1360). (Obsérvese que ninguno de los dos términos aparece en Sófocles).

De los pasajes homéricos en que kpasía funciona como complemento directo destacamos $\mathrm{Od}$. 20.17, donde el héroe fecundo en recursos le habla a su propio corazón.

En el texto euripideo que comentamos la heroina "mueve, remueve, agita"(es una innovación el empleo de KŁvé $\omega$ en contextos semejantes) su corazón y su cólera, como si fueran dos realidades físicas separadas o dos objetos directos, referidos, respectivamente, al todo y la parte. La duda nos entra cuando leemos el v. 590, en boca de Jasón: "tú...que, ni aún ahora,

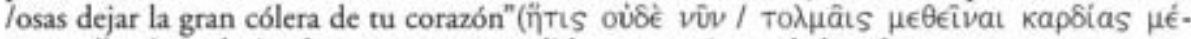
yav Xó̉ov), es decir, el corazón es entendido como asiento de la cólera.

(52) Para su etimologia se admite el radical "swëdh, de la misma raiz que el pronombre reflexivo. Cf. P. Chantraine, Dictionnaire tetymologique, p. 408.

De acuerdo con los datos ofrecidos por el $T L G$, tenemos el sustantivo indicado en Hom. (3), Hes. (9: véase qué diferencia con respecto a los poemas homéricos. Acúdase, por ejemplo, a Op. 67 y 167, para ver cómo entra en el campo propio del modo de ser), A. (4: siempre en plural. Es relevante Pr. 184 donde el Coro se refiere a las "costumbres inaccesibles y corazón inflexible" de Zeus), S. (3: en singular. Sobresale Ai. 595, donde Áyax le replica a Tecmesa que piensa locuras "si mi carácter crees educar al momento"), E. (11. Cf. , en singular, Supp. 869 y 907, donde se alude al modo de ser de Capaneo y Tideo, respectivamente).

(53) Cf. Op. 67, 167.

(54) De los usos (33) homéricos de ăyplos destacamos unos cuantos: cuando se atribuye a la

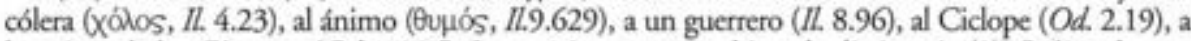
la estirpe de los Gigantes (Od. 7.206). Los trígicos conocen bien el adjetivo: A. (9), S. (21: destaca Ant. 973, donde califica a la madrastra (Idea, esposa de Fineo) que mató a los hijos habidos por su marido en un matrimonio anterior), y E. (28. Dos en la obra que estudiamos. En el otro pasaje, Med.1343, Jasón le llama a Medea, "leona, no mujer, que tienes / naturaleza más salvaje que la tirré-

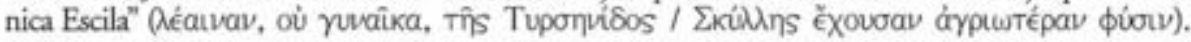

(55) No abunda en nuestro poeta la atribución de ese adjetivo a personas. Sólo hemos localizado dos ejemplos más: referido a Egisto, por boca de Electra (El. 1116) y calificando a Penteo, en labios de Tiresias (Ba. 361). 
Comentemos ahora la expresión "odiosa naturaleza de un corazón or-

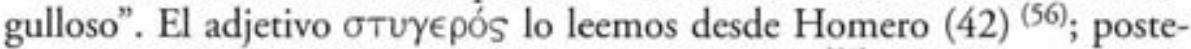
riormente, lo emplean, entre otros, los tres trágicos ${ }^{(57)}$. Por su lado, $\phi u ́ \sigma t s$ es un término de contenido riquísimo en toda la literatura griega: aunque presente desde Homero ${ }^{(58)}$, es en los presocráticos donde, desde el siglo VI a.C., adquiere matices y sentidos como "génesis" y "desarrollo"-"crecimiento" que serán básicos para la institución y conformación, por ejemplo, de una medicina racional (59) a partir de los últimos decenios del siglo V. Los trágicos registran en buena medida el sustantivo ${ }^{(60)}$. Nuestro autor, por su lado, conoce varios matices del vocablo ${ }^{(61)}$.

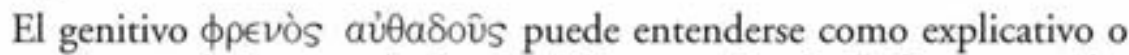
epexegético, es decir, a modo de aposición o paréntesis: "odiosa naturale-

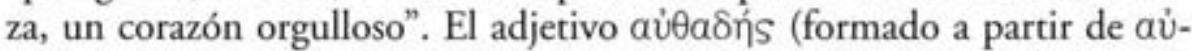

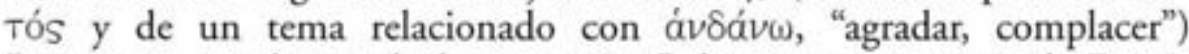
"arrogante, que hace sólo lo que quiere", lo tenemos a partir de Esquilo ${ }^{(62)}$. En Eurípides es significativo el uso del mismo y del sustantivo correspondiente ${ }^{(63)}$. Ambos subrayan, en cierto modo, el modo de ser de la

(56) Ciñéndonos a seres divinos y humanos, el calificativo lo merecen Hades (II. 8.368), Ares (II. 2.385; 18.209), Erinis (Il. 9.454; Od. 20.78), Erifile (Od. 11.326), una madre espe-

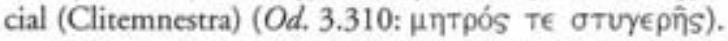

(57) A. (7), S. (9. En Ai. 1214 se atribuye a un demon), E. (10, de ellas 4 en nuestra obra, en la que se recogen las dos únicas ocasiones - Med. 103, 113 - en que nuestro poeta lo atribuye a personas).

También referido a personas, lo hallamos, precisamente, en boca de la protagonista, unos versos más abajo de los que ahora examinamos (Med. 112-4):

... O Oh malditos

hijos de odiosa madre! ¡Así muráis

con vuestro padre y toda la mansión desaparezca!

ఉె кaтápatoi

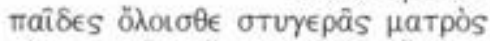

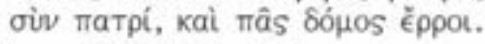

(Recordemos $\mathrm{Od}$. 3.310, citado en nota anterior). En realidad, Medea se merece el adjetivo por la maldición fulminante pronunciada contra sus hijos.

(58) Sólo en una secuencia: $\mathrm{Od}$. 10.303, con el sentido de "forma, apariencia externa".

(59) El Corpus hippocraticum recoge el sustantivo en 621 ocasiones.

(60) A. (9), S. (37), E. (60).

(61) Algunos ejemplos: 1) "aspecto físico, figura": $B a .1358 ; 2$ ) "naturaleza, orden natural": Ph. 395; Fr. 170.2: "naturaleza del ser humano"; 3) "modo de ser natural, índole, carácter": Med. 103; Fr. 139.2: "carácter bárbaro"; etc.

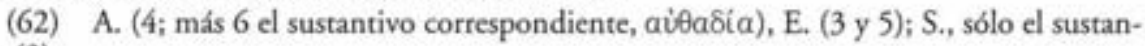
tivo (2).

(63) El adjetivo: 104, 223 (Medea afirma que no elogia al ciudadano orgulloso que resulta odioso para sus conciudadanos); el sustantivo en 621 (Jasón hiere a la heroína afirman-

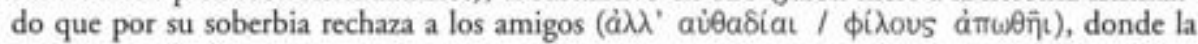


protagonista. Muy significativo resulta que la mitad de empleos euripideos de ambos términos estén concentrados en la pieza que examinamos.

Es relevante la mención de la "nube de sollozos", sinestesia en que intervienen los sentidos de la vista y del oído; a esa nube que está en sus comienzos - es decir, si hasta este momento se nos había hablado sólo de lágrimas ${ }^{(64)}$, ahora se mencionan los sollozos-, Medea le va a prender fuego con su $\theta$ unós. En una palabra, la rabia de la heroína logrará que la nube produzca un rayo.

Explicación adicional merecen, sin duda, los dos adjetivos que vienen

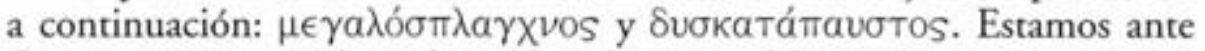
dos términos especiales, rebuscados, de cinco sílabas cada uno, que vienen a describir aspectos poco conocidos de una persona excepcional.

El primero, "de grandes entrañas", innovación euripidea, llamó la atención de Galeno, que, tras referirse al hombre "sin entrañas" (d́splanchnos) $)^{(65)}$, o lo que es igual, sin valor, pasa a hablar de la heroína: "El contrario se llama de 'grandes entrañas' ${ }^{(66)}$, como Eurípides presenta a Medea dotada, sin duda, de grandes entrañas, en posesión de todas las facultades de las tres vísceras y de fuertes impulsos. Pues propone una mujer deseosísima, muy irascible y, al mismo tiempo, terrible por su razonar... De lo

ironía fundamental consiste en el uso de $\phi i \lambda o s$ que funciona como sustantivo. Jasón, con su nueva boda ha roto los juramentos prestados y no puede ser considerado $\phi i \lambda o s$ de Medea desde ningún punto de vista, por mucho que se esfuerce en demostrar que quiere ayudar social y económicamente a los hijos de su primer matrimonio) y 1028, momento en que la protagonista reconoce su forma de ser: "Oh desdichada por mi arrogancia" (

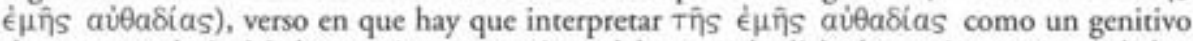
de causa; es decir, Medea, según sus propias palabras, es desdichada precisamente por haber sido orgullosa.

(64) Cf. Med. 25.

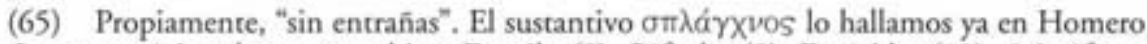
(9). Los tres trágicos lo conocen bien: Esquilo (8), Sófocles (2), Eurípides (12), Aristófanes (19). El Corpus hippocraticum (64) aporta algunos detalles sobre esas entrañas: Prorrh. 2. 42

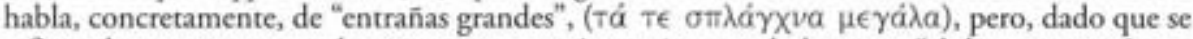
refiere al aspecto externo de una persona, mejor seria entenderlo como "abdomen prominente". Mucho más tarde, en Galeno, normalmente en plural, no tiene un significado unívoco: es distinto de los intestinos (4.277.2); son tres (cerebro, hígado, corazón: 5.363.18; o hígado, bazo y rin̄ones: 19.115.1 TLG); son cuatro (superiores: corazón y pulmón; e inferiores: hígado y bazo. Cf. 4.196.17).

(66) Me $\gamma a \lambda o ́ \sigma \pi \lambda a \gamma \chi v o s$, después de Eurípides, lo tenemos en el Corpus hippocnaticum (4), Galeno (14), Pseudo-Galeno (1), Erotiano (1) y Oribasio (3).

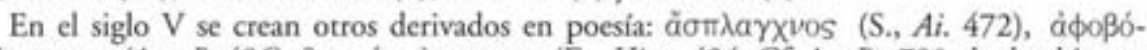

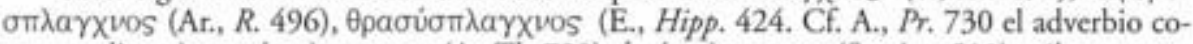

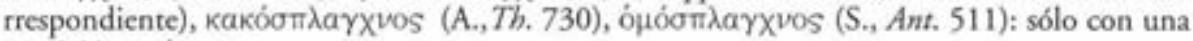
aparición cada uno. 
irascible de su vehemencia — qué resentimientos tuvo contra sus hijosno son pequeños los indicios. Y sobre la racionalidad de su inteligencia (pues también en estos aspectos la presenta Eurípides no como a una más) no son pequeñas las pruebas; lo maquinado para vengarse de los enemigos y todo lo que discurre respecto a sí misma, conteniendo y persuadiendo a su ánimo a fin de apartarse de actos impíos. De manera que, con razón, dice Eurípides de ella: '¿Qué hará/ un alma de grandes entrañas, altiva,/ mordida por las desgracias?/ (67). Así pues, esa es de grandes entrañas; en cambio, carece de entrańas y las tiene pequeñas aquel cuyas tres partes del alma son insignificantes, pequeñas y de movimientos lentos y difíciles" (68).

El segundo lo encontramos por vez primera en Esquilo (1) ${ }^{(69)}$; luego, en nuestro poeta, tan sólo en este pasaje ${ }^{(70)}$. Es uno más de los muy numerosos compuestos con $\delta v \sigma$ - empleados por el trágico ${ }^{(71)}$.

8. En la citada escena anapéstica la nodriza alude a otros hechos significativos: el aislamiento y silencio de su señora:

Y ella, en la alcoba, consume su vida, mi señora, sin aliviar nada su corazón con palabras de ninguno de sus amigos. ${ }^{(72)}$

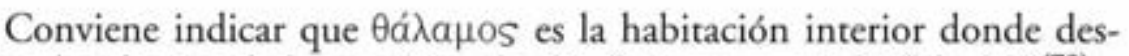
cansan los dueños de la mansión: de ahí, "cámara nupcial", "alcoba" (73).

En los poemas homéricos aparecen los sustantivos Bíotos y ßıтт́,

(67) Med, 108-110.

(68) Gal., 5.317.7.

(69) Ch. 470, a propósito del dolor.

(70) Es muy poco utilizado en la literatura posterior. En el siglo IV, por ejemplo, tan sólo lo recogen Demóstenes y Teofrasto, sólo una vez cada uno.

(71) Examinados en conjunto los datos del TLG sobre el uso del elemento $\delta v \sigma-$, tenemos: Hom. (107), A. (221), S. (252), E. (482). (La comedia, en cambio, lo usa poco: Ar. sólo 54). En nuestro trágico, Med. (37) y, a continuación, Hipp. (36) son las piezas que cuentan con más ejemplos.

No entro en el examen de $\psi v x n ́$, término polisémico en nuestro autor ("alma, vida, ser, persona, carácter", etc.), que requeriria un estudio especial. De la importancia ocupada en las obras euripideas puede darnos noticia la evolución de su uso desde los poemas homéricos: Hom. (80), A. (34), S. (37), E. (126).

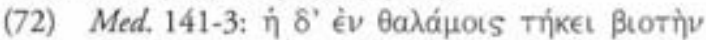

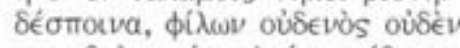

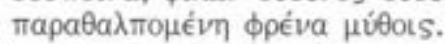

(73) Bien conocido por Hom. (71); recogido por los tres trágicos: A. (3), S. (5) y E. (44). Adviértase el elevado número de secuencias en nuestro poeta. 
"medios de vida", "vida", utilizados luego por los trágicos ${ }^{(74)}$. Ya desde Homero contamos con un precedente para la imagen de "fundir", "consumir" la vida ${ }^{(75)}$. También es homérico $\theta a ́ \lambda \pi \omega$, "calentar, reconfortar, aliviar", pero es una innovación euripidea el compuesto. Sin duda tiene relevancia el hecho de aliviar a una persona enfadada, retraída y silenciosa, mediante la conversación, la palabra ${ }^{(76)}$.

9. Medea se presenta ante las mujeres corintias (el Coro, en realidad) para evitar la censura ${ }^{(77)}$. Entre sus afirmaciones, expuestas con meridiana claridad, destacamos sólo algunas que contribuyen, según creo, a definir su personalidad: las mujeres son el ser ${ }^{(78)}$ más desdichado entre todos los animados ${ }^{(79)}$ y dotados de razón ${ }^{(80)}$; han de comprar un esposo con excesivo gasto de dinero ${ }^{(81)}$ y conseguir un dueńo de su cuer-

(74) Hom. (40-1), A. (13-4), S. (10-5), E. (51-17). Nótese la progresión en el empleo del segundo término. Med. ofrece cuatro ejemplos de cada uno: respectivamente, 1037, 1102 , 1107,1355 , es decir, hacia el final de la obra, y 141, 147, 415, 993.

(75) Od. 19.264: Penélope consumía su ánimo llorando por su esposo.

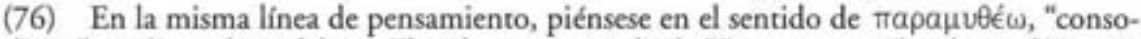
lar, aliviar" mediante las palabras. El verbo, presente desde Homero, es utilizado también por nuestro trágico (Cf. $L A$ 1617, donde Clitemnestra duda de que intenten consolarla (rapaju-

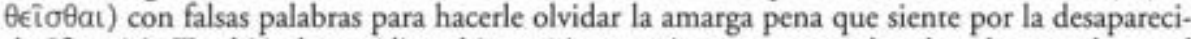
da Ifigenia). También los médicos hipocráticos supieron comprender el poder curador, o al

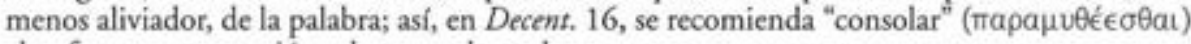
al enfermo con atención y buena voluntad.

(77) Med. 214-66. Aunque Medea intenta identificarse con las mujeres del Coro, su situación es distinta (las condiciones de su alianza con Jasón; su pasado mítico; la muerte infame que dio a su hermano Apsirto (vv. 166-7); lo sucedido en Yolco con las hijas de Pelias; etc.). Ahora bien, la heroína logra su propósito: atraerse la simpatia del Coro y conseguir su silencio (v. 263: $\sigma \curlywedge \gamma a ̂ v)$ ), cuando llegue el momento decisivo.

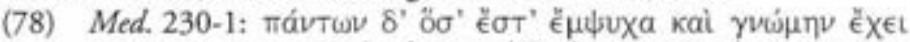

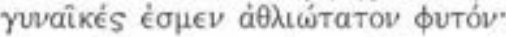

Ya en Homero leemos que el hombre es el ser más desgraciado de cuantos respiran y se mueven por el suelo (Il. 17.446-7). Aparte de ese topos literario, referirse a las mujeres como

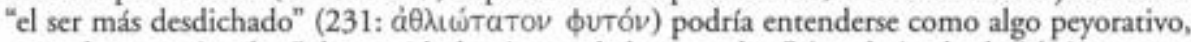
pues el neutro фuтóv, "planta, árbol, criatura de la naturaleza" (un derivado de $\phi i ́ w)$, rara vez se atribuye a personas; sí, en cambio, a árboles y vegetales, productos del suelo. Cf. A., Supp. 281, atribuido a las hijas de Dánao, como algo engendrado por el Nilo. Sófocles no lo emplea, pero, en nuestro poeta, contamos con un pasaje en que Hipólito, sintiéndose engañado por la nodriza que le ha hecho jurar no contar nada, habla con gran dureza de "quien recibe

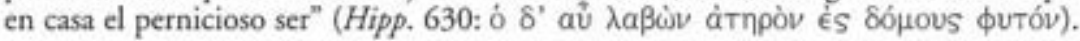

(79) El adjetivo $\tilde{\mu} \mu$ $\chi 0 S$, "dotado de alma, de vida", es bastante raro: Simon.(1), S. (3), E. (5). Más frecuente en prosa: Hdt. (6), por ejemplo. Es interesante este ejemplo hipocrático (Vict. 1.28): "Y porque el alma es la misma cosa en todos los animados; el cuerpo de ca-

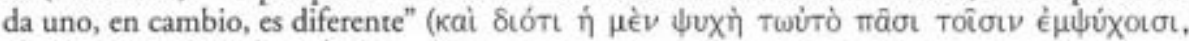

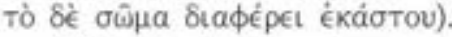

(80) Es, sin duda, relevante la afirmación de que las mujeres tienen "pensamiento, buen

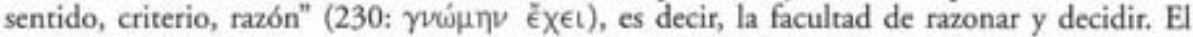




\section{po ${ }^{(82)}$; la separación no les reporta buena fama y no es posible rehusar al esposo ${ }^{(83)}$; si éste convive con ella y no le impone el yugo por la fuerza,}

término үvwín surge en Teognis, siglo VI, y es recogido en numerosos autores del V (los historiadores y médicos lo emplean mucho): los trágicos también lo usan con largueza (A., 18; S., 38; E., 54). En nuestro autor leemos, a propósito de Fedra, que "intentó, con la razón,

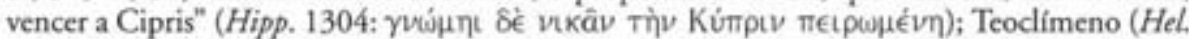
1687) les dice a los Dioscuros "alegraos por Helena, a causa de su nobilísimo / criterio, el cual

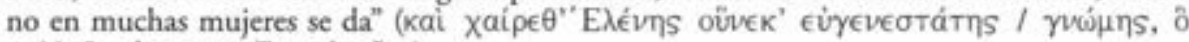

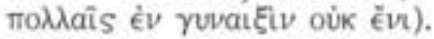

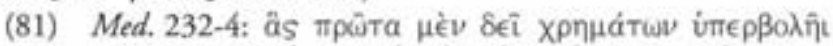

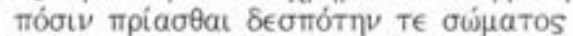

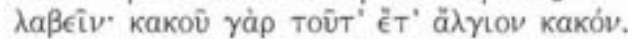

En Atenas, por los años en que se representó la obra, era normal que la novia aportara una dote (consistente ya en bienes, propiedades o riquezas - $\phi \in \rho v \eta \dot{-}$ - ya en dinero matrimonio, entregándosela, en depósito, a su esposo. En los poemas homéricos, en cambio, solia suceder que el pretendiente (o su familia) diera unos regalos ( $\epsilon \delta v a)$ a los padres de la novia.

En Med. 956 la heroína entrega a sus hijos unos presentes para que se los den a la recién casada como parte de la dote ( $\phi \in p v a i$ ) que ha de aportar al matrimonio.

No obstante nuestro trágico parece no preocuparse mucho por lo que hoy entenderíamos como anacronismos, es decir, presentar ante los atenienses costumbres de la época heroica como si fueran contemporáneas o adjudicar al mundo de los héroes homéricos normas propias del siglo $\mathrm{V}$.

(82) Medea cree que mal (Kakóv) más doloroso todavía que "comprar un esposo" es

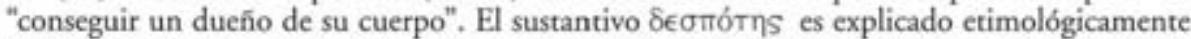
a partir de "dems y "potis, es decir, "señor de la casa". Lo hallamos en griego desde el siglo VII: Arquíloco y Safo son los primeros en registrarlo. Los trágicos hicieron abundante uso del mismo: A. (25), S. (17), E. (130). Nuestro autor, pues, sintió especial predilección por el término: sobresalen, Alc. (12), Hel. (10), Hipp. (9), etc. Med. cuenta con 5 ejemplos. Del uso sintáctico, con genitivo partitivo, destacamos algunos ejemplos relevantes en que se trata de mujeres dependientes de un señor: Hel. 572, cuando Helena (aún no reconocida) le pregun-

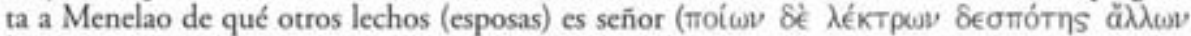
Ëфu;); Tr. 699, donde Hécuba le recomienda a Andrómaca que honre a su dueño de entonces ( do peyorativo, a veces, de tal sustantivo, como vemos en $H F$ 141, cuando el sanguinario Lico se presenta ante Anfitrión y los suyos con un ofensivo: "ya que me he convertido en dueño de

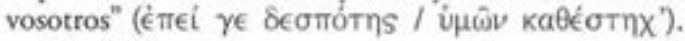

También merece un comentario el sustantivo $\sigma \omega \hat{\mu} \mu$. Presente en Hom. (8), recogido por A. (29), S. (25) y E. (118) indica tanto "cuerpo" ("cadáver" en Homero), como "persona", "vida". En nuestro autor, sobresalen Supp. (13), HF (11), etc. Med, sólo cuenta 5.

Desde los poemas homéricos contamos con el neutro кaкóv - veamos unos pocos ejemplos de la Odisea: como sujeto $(\mathrm{Od} .2 .166)$, predicado nominal $(\mathrm{Od} .4 .697)$, complemento directo $(\mathrm{Od} .9 .255)$, acusativo neutro interno $(\mathrm{Od} .4 .237)$, etc.-. Presentaré los datos obtenidos del $T L G$, sin distinguir los usos del adjetivo y los sustantivados, limitándome, además, a esa forma del neutro singular: Hom. (141), A. (37), S. (56), E. (94). Entre los numerosos empleos de nuestro poeta, destacan dos piezas: Hipp. (21) y Med. (18): la nuestra, pues, es la segunda en número de usos.

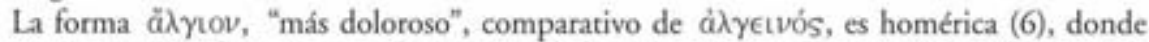
funciona sustantivada y sin segundo término de la comparación; desde A. (1), S. (1) y E. (2) la hallamos con la construcción propia del comparativo. 
su vida es envidiable, pero, de lo contrario, menester es morir ${ }^{(84)}$; el varón, cuando se cansa de convivir con los de dentro, se marcha afuera y li-

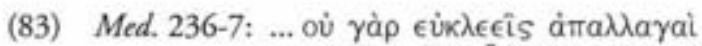

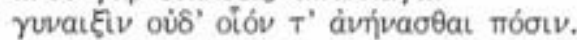

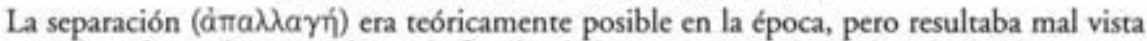
en general, $y$, de modo especial, por la familia de la mujer. Así cabe deducirlo de algún testimonio literario (Cf. Anaxandr., Fr. 56. Este cómico de la primera mitad del IV escribe así :"difícil, te lo digo yo, y cuesta arriba, hija, / es el camino para volver hacia su padre, a su casa, / desde su marido, cualquiera que es mujer honrada. / Pues el camino de ida y vuelta es aca-

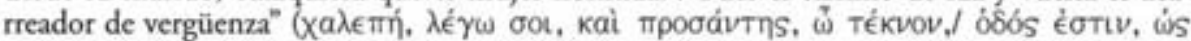

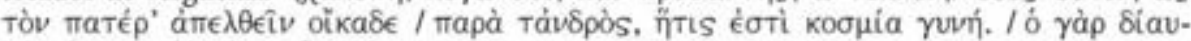

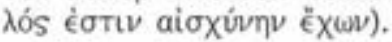

"Rehusar" (ảvaínouai) al esposo era casi imposible en los años de la representación de nuestra pieza: sólo se conseguía en ciertos casos de crueldad o infidelidad. La expresión euripidea puede indicar, según Mastronarde, rehusar al esposo "sus derechos a la relación sexual". En Hipp. 14 leemos acerca del protagonista: "rechaza el lecho y no prueba el matrimonio"

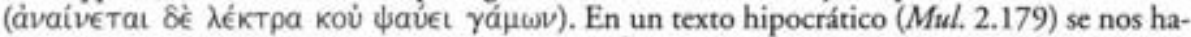

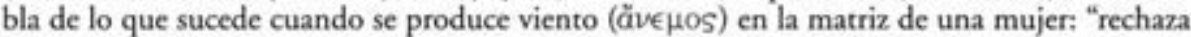

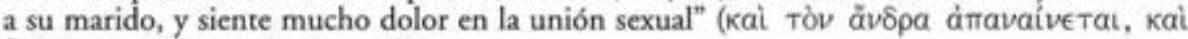

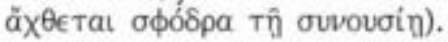

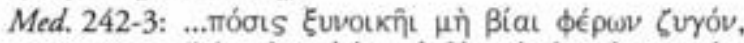

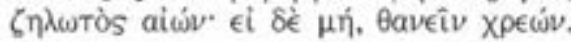

El verbo бuvoukéw, "cohabitar, compartir el hogar", lo leemos desde Safo. Heródoto lo presenta con frecuencia en sentido sexual. Entre los trágicos, ni A. (1), ni S. (5) lo utilizan con tal connotación, pero sí nuestro autor, que es el que con más frecuencia lo emplea (18); en

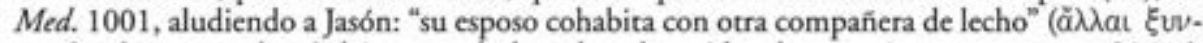

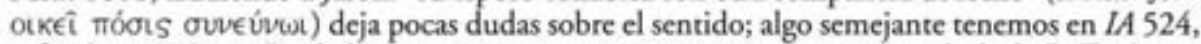

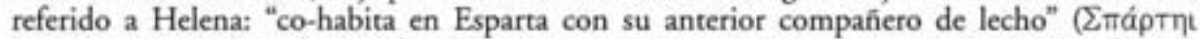

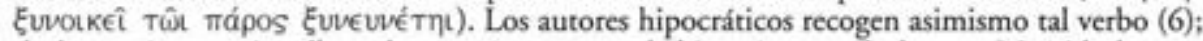
de las mujeres escitas llamadas saurómatas que habitan junto a la laguna Meótide leemos (Aër. 17): "no pierden la virginidad hasta que han matado a tres enemigos y no cohabitan an-

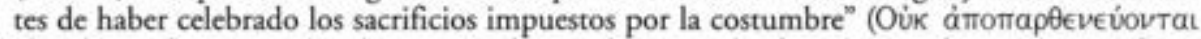

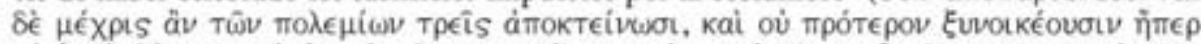

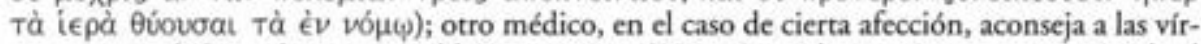
genes que cohabiten lo antes posible con varones (Virg. 1); en dos ocasiones se recomienda al médico: "convencer a la virgen de que cohabite con un varón" (Mul. 127; Nat. mul. 3: Tìv

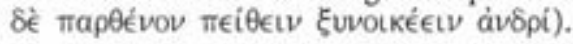

Bien conocido por los poemas homéricos es el sustantivo \vyóv, "yugo". En los trágicos adquiere otros sentidos metafóricos, pues no se trata ya de lo que une a dos seres, sino de lo que se impone sobre muchos: se habla del yugo $\delta 0 u ́ \lambda t o v$, "propio de la esclavitud, esclaviza-

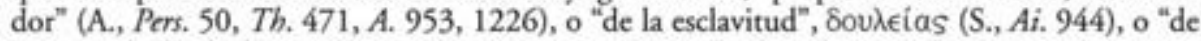
la necesidad", ávárins (S., Fr. 591.6; E., Or. 1330; Fr. 475.1): en ambos casos, el genitivo es explicativo, equivalente a una aposición.

Por su lado, Bía, sustantivo que aparece ya en los poemas homéricos, tiene aquí el sentido de "violencia", "fuerza bruta". Precisamente, en dativo, equivale a realizar algo "por la fuerza", por oposición a lo que se obtiene de modo natural o legal; así, Od. 15.231; A., Pr. 24; etc.

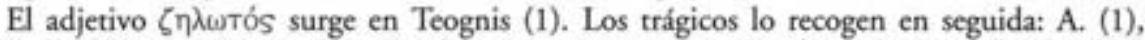
S. (1), E. (8): nuestro autor lo utiliza bastante, como vemos. La idea es la de ser "envidiable"

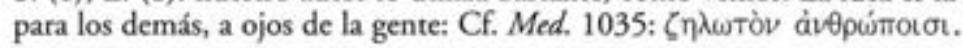


bera de náusea su corazón, dirigiéndose a casa de un amigo o de alguien de su edad ${ }^{(85)}$; las mujeres, en cambio, han de mirar a un solo hombre ${ }^{(86)}$; los varones afirman que las mujeres pasan una vida carente de peligros en el hogar, mientras ellos combaten con la lanza, pero es preferible, tres veces más, permanecer junto al escudo que tener un solo parto ${ }^{(87)}$.

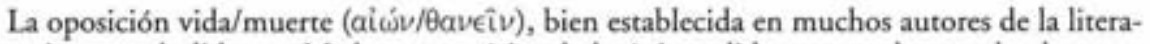
tura griega, es aludida por Medea a propósito de la única salida que queda cuando el esposo se impone por la fuerza en el matrimonio.

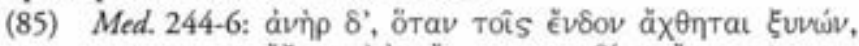

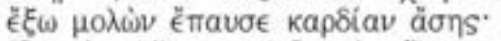

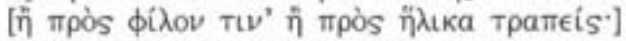

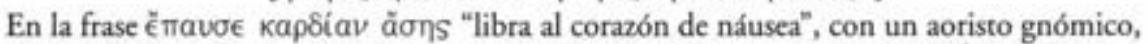
tenemos el término ăơ, "disgusto, saciedad, náusea", muy raro en poesía (Cf. Sapph., 1.3; Anacr., 2.1), pero frecuente en los escritos hipocráticos, como término técnico (23). Cf. Epid.

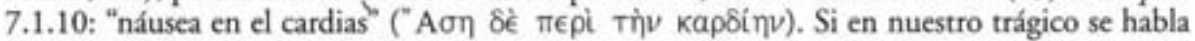
del "corazón", en el autor hipocrático se hace referencia al cardias, orificio de entrada desde el esófago al estómago. Es el único lugar euripideo en que encontramos el vocablo, ausente en los otros trágicos.

El verso señalado con corchetes es una interpolación según los especialistas. Podría ser un añadido para mitigar la expresión $\tilde{\epsilon} \xi \xi(\omega) \lambda \omega v$, que, según Wilamowitz, significa irse fuera de casa para unirse sexualmente con una prostituta. Véase, Mastronarde.

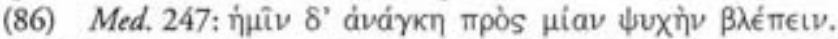

Desde Homero es frecuente el uso de àvá $\gamma \mathrm{k} \eta$, "necesidad", especialmente como sujeto de oraciones nominales puras cuyo predicado nominal es un infinitivo, como vemos en el texto indicado. La evolución de su empleo es indicativa: Hom. (40), A. (17), S. (21), E. (58). En nuestro poeta, Med., con cinco apariciones, es la segunda en importancia numérica, tras Hec.(8); resulta significativo que sea la protagonista quien pronuncie siempre el término.

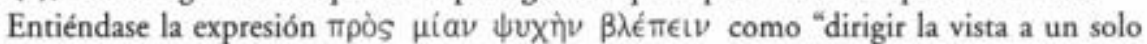
ser" o "una sola persona", donde resulta incierto de qué sexo se trata, si bien, por el contexto, hemos de pensar en el varón. El uso de $\psi v x \tilde{n}$, polisémico, se incrementa mucho desde Homero. Limitándonos a la grafía y forma $\psi v x$ í tenemos: Hom. (63), A. (19), S. (31), E. (94). Si tenemos en cuenta las demás formas de ese sustantivo, en sus distintas grafias, pueden contarse más de 130 secuencias. En Med., por ejemplo, lo tenemos en 110, 226, 247, 474, 968, 1219.

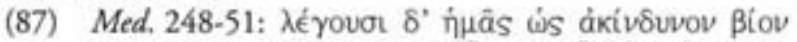

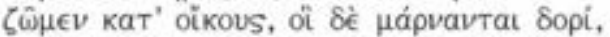

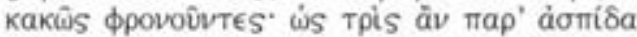

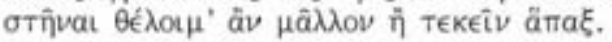

Es significativa, nos parece, la presencia de $\lambda \hat{\text { jovou }}$ en este pasaje. Nuestro poeta utiliza con frecuencia la expresión (27); Med. $(3: 248,684,833)$ figura entre las piezas que más la contienen (el mismo número de secuencias tenemos en Supp. y El.). El trágico usa la fórmula cuando quien habla quiere descargarse de la responsabilidad de lo que afirma (por ejemplo, en cuestiones míticas. Véase Med. 833: "donde dicen que las Musas Piérides engendraron a la rubia Harmonía").

Resulta evidente desde el mundo homérico la diferenciación establecida entre actividades propias del hombre y las pertinentes a la mujer. En el canto sexto de la Iliada, Andrómaca le 
10. Medea desea y necesita ganarse la simpatía del Coro, para lo que recurre a expedientes varios, especialmente a la oposición varón/mujer, subrayando la situación desfavorable del sexo femenino frente a la libertad de los varones para ausentarse de casa cuando las cosas no andan bien. Es más, en propio provecho, no duda en recurrir a alguna falsedad, como decir que había sido "tomada como botín desde un país bárbaro $^{n}{ }^{(88)}$, cuando no hay ninguna variante de la saga mítica que nos auto-

pide amorosamente a Héctor que se quede a salvo en la torre donde está y ni deje huérfano a su hijito ni viuda a ella, $y$, además, que ponga tropas donde el muro troyano es más accesible. El defensor de Troya, amablemente, pero con firmeza, la manda a las tareas del hogar, al telar

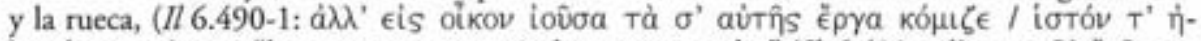

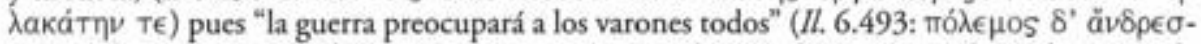

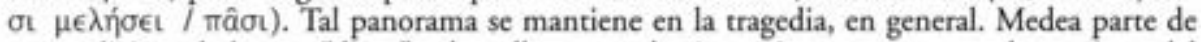
esa tradición, de lo que "dicen" sobre ella, pero, al mismo tiempo, provoca a las mujeres del Coro, haciéndoles ver que es muchísimo más importante un solo parto que luchar con la lanza, con lo cual se tambalea la oposición mujer-casa/varón-ejército.

De ákívouvos ßíos ya nos habla Simon. (Fr. 18.3) en el siglo VI a.C., precisamente en la primera aparición del adjetivo. E. (2) es el único trágico que lo recoge; está presente también en Th. (6), X. (9), y en el Corpus hippocraticum (26), por ejemplo; entre los médicos se aplica a fiebres y otras afecciones que no suponen un "peligro" para la vida del enfermo.

Las palabras de la heroína van referidas al Bíos, la vida, el tipo de vida, que las mujeres hacen dentro de su hogar. Dos veces seguidas se opone el hogar al ejercicio de las armas; en la segunda se contrapone el mantenerse firme junto al escudo a parir un hijo. Esa contraposición nos permite pensar que, para Medea, parir era un acto difícil, peligroso, a consecuencias del cual la madre moría en muchas ocasiones, como diversos estudios especializados nos enseñan.

El verbo $\mu a ́ p v a \mu a t$, típicamente homérico (56) (cf. Il. 16.195, "esforzarse con la lanza":

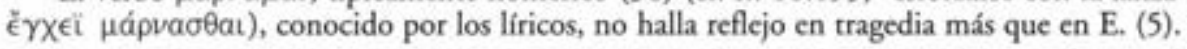

Destaquemos el adverbio kakîs: Hom. (21), A. (21), S. (42), E. (149); puede verse la preferencia de nuestro autor por tal vocablo. Med. (20) es la pieza que más ejemplos ofrece, seguida a larga distancia por $H F(10)$. Merecería la pena examinar con detalle cada uno de los ejemplos que encontramos en nuestra tragedia, pero nos llevaría más espacio del razonable. Destaquemos, subrayados, los pasajes en que aparece en boca de la heroina: 38,55, 250, 280 , $364,458,464,470,474,507,533,567,788,805,815,892,1014,1302,1386$. En el pa-

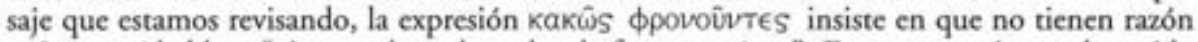
quienes así hablan: "piensan de mal modo, de forma errónea". En otras ocasiones el sentido apunta a la intención hostil, la animadversión hacia otro. Véase la construcción, con distintas formas del mismo verbo, en esta misma obra: Med, 464, 892, 1014.

A su vez, el adverbio tpis - Hom. (48), A. (4), S. (5), E. (3)-, aparte de su valor usual, "tres veces", adquiere otro hiperbólico, "muchas, innumerables veces"; pudiera estar dotado de ese sentido en el lugar que examinamos, pues la posición enfática del adverbio, y, además, la repetición de la partícula ăv, quieren subrayar la vehemencia con que están dichas estas palabras.

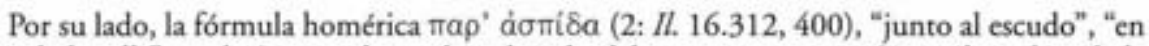
línea de batalla", es decir, con el escudo colocado delante como protección, sólo es heredada por nuestro poeta (5).

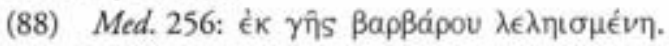


rice a aceptar tal aserto. Esta primera intervención de la heroína acaba con estas palabras:

...Una mujer, en lo demás, resulta llena de miedo

y cobarde ante la pelea y para mirar el hierro.

Mas, si respecto al lecho injuriada se ve,

no existe otro corazón más sanguinario. ${ }^{(89)}$

De estos últimos versos el espectador avisado podría obtener algunos indicios de por dónde iban a transcurrir los hechos. La expresiva fórmula "estar llena de miedo" la encontramos en Esquilo por primera vez ${ }^{(90)}$; luego, en Eurípides, la hallamos dos veces en femenino ${ }^{(91)}$ y otras tantas en masculino ${ }^{(92)}$. El verso siguiente supone, en cierto modo, una alteración de la división de funciones propias de varones y mujeres: Medea, sin du$\mathrm{da}$, de forma provocadora, alude al mundo varonil, el enfrentamiento bélico y el uso de las armas; de modo aparente, para mostrar la inferioridad femenina en tal campo, pero, en realidad, para poner al Coro de su lado en los sucesos que se avecinan.

Nuestro autor emplea aquí кakń, con el sentido de "cobarde" (93), es decir, con el adjetivo que, en masculino ${ }^{(94)}$, resultaba el peor calificativo que se podía decir de un guerrero homérico ${ }^{(95)}$. Sobresale, asimismo, el sustantivo ả $\lambda \kappa \eta$, "fuerza que permite defenderse", viejo término homérico, conocido por los trágicos ${ }^{(96)}$; hasta entonces patrimonio de los varones, pero ahora referido, con no poca provocación, al comportamiento femenino.

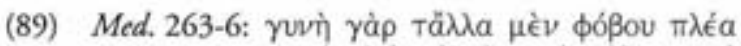

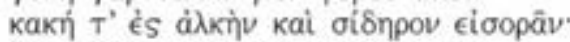

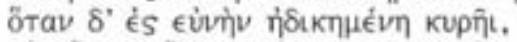

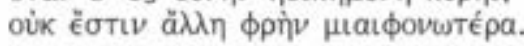

(90) Pr. 696: Prometo lo dice del Coro, como singular colectivo. En Pers. 603 se trata de un plural neutro.

(91) Med. 263, 903 (Medea de sí misma).

(92) Heracl. 473: Demofonte alude a sí mismo; El. 25, el campesino habla de Egisto.

(93) Cf. Hec. 348, también en femenino.

(94) Cf. Il. $2.365 ; 6.489 ; 8.153 ; 13.279 ;$ Od. 3.375;10.301; etc.

(95) El adjetivo lleva dos precisiones: un giro en acusativo con és, que funciona como acusativo de extensión o relación, "en cuanto", "por lo que refiere a", y un infinitivo de limitación.

Partiendo de los datos totales ofrecidos por el TLG a propósito del tema kak-, tenemos: Hom. (500), A. (324), S. (507), E. (1318). En nuestro poeta, por número de apariciones, sobresalen: Hipp. (108), Med. (86), Or. (85), Hec. (74), Andr. (68); la tragedia que menos contiene es Bac. (22).

(96) Hom. (69: 58 Il., 11 Od.), A. (5), S. (5), E. (23). 


\section{Sin duda relevantes son las alusiones al "hierro" (97), al lecho ${ }^{(98)}$, y a la condición sanguinaria ${ }^{(99)}$ del sexo femenino.}

(97) Homero conoce el hierro ( $\sigma i \delta$ mpos lo hallamos citado en treinta y una secuencias; además, tenemos derivados de tal sustantivo en otros diecisiete textos), que, según los estudiosos, comenzó a ser usado después de la guerra de Troya: los héroes épicos, en cambio, utilizan normalmente armas de bronce (el hierro lo tenemos, con frecuencia, en comparaciones o excursos; pero, incluso referido al mundo de los héroes, se habla de la punta de hierro de una lanza (Il. 4. 23); un cuchillo (Il. 18. 34); Penélope, aparte del arco, les trae el "grisáceo hierro" a los pretendientes en $O d .21 .81$; véanse, además, $O d .21 .97 ; 114 ; 127 ; 24$. 168; etc.

Los trágicos emplean el sustantivo en distinta medida: A. (4), S. (6), E. (34). En casos como el presente debe tomarse como una metonimia en virtud de la cual un instrumento (espada u otra arma por el estilo) recibe el nombre del material de que está formado.

Un punto de verdadero interés es la afirmación de que las mujeres sienten rechazo al "mirar" el hierro, es decir, se muestran cobardes sólo con verlo. En cambio, la protagonista, en el momento sublime, no tendrá reparos en usar la espada (v. 1244) contra sus propios hijos.

(98) Si €ùví es un sustantivo homérico, donde adquiere claro sentido sexual, especial-

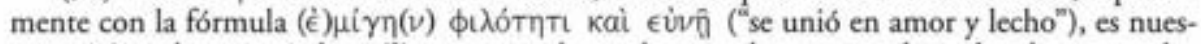
tro trágico el que más lo utiliza en sus obras, destacando con mucho sobre los otros dos tragediógrafos.

Eurípides, como en tantos otras ocasiones, se muestra experto en el empleo de términos

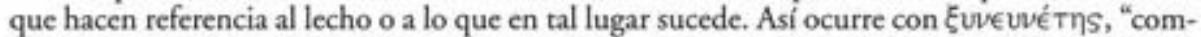
pańero de lecho", que no aparece hasta él; lo emplea en cinco ocasiones. También es el pri-

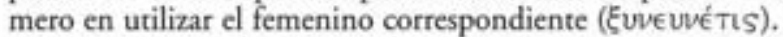

Conviene señalar que $M e d$. es la tragedia euripidea donde más veces está registrado el citado sustantivo (7): $88,265,570,642,673,1027,1338$. De los varios contextos en que aparece

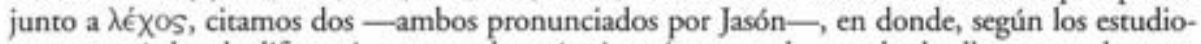
sos, no está clara la diferencia entre ambos términos (aunque el segundo de ellos, normalmente, hace referencia a la madera de que suele estar formado el cuerpo esencial de la cama):

a) Med. 568-573: Tampoco lo afirmarias tú, si no te molestara tu lecho.

Mas a tal punto habéis llegado las mujeres que,

yendo derecha vuestra unión, pensáis tenerlo todo;

y si algún infortunio, respecto al lecho, sobreviene,

lo más conveniente y más hermoso por muy hostil

lo tenéis...

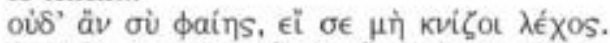

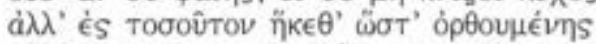

Є

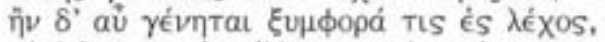

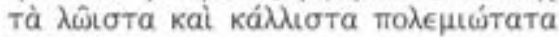

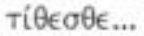

Abundan los dobles sentidos en estos versos. El primer $\lambda e ́$ Xos podría referirse al reciente matrimonio de Jasón, o a la joven casada con el héroe. A su vez, en €ủví puede verse algo más que el lugar material donde se descansa, pues, por metonimia, puede aludir a quienes lo usan, es decir, a la pareja casada o unida, a la unión marital.

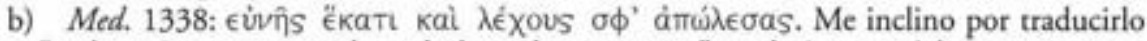

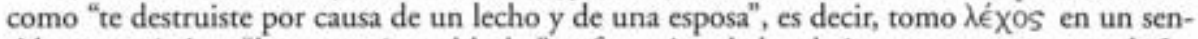
tido metonímico: "la que está en el lecho", referencia velada a la joven y nueva esposa de Jasón (Cf. otros ejemplos semejantes en 570 y 642).

(99) ulaıфóvos, "manchado con un crimen, con sangre", lo tenemos en Homero cuatro veces, aplicado siempre a Ares, el dios sanguinario. Lo recogen los trágicos: A. (2), S. (1) 
11. Creonte, rey de Corinto, le dirige la palabra a la heroína de modo harto singular:

"A ti, la de rostro sombrío e irritada con su esposo, Medea...". (100)

Nos fijaremos con cierto detenimiento en $\sigma \kappa \nu \theta \rho \omega \pi$ śs $^{(101)}$, un adjetivo singular, algo difícil de explicar, si sólo se refiere al aspecto visible del "rostro", pues la máscara permanente no permitiría, sin duda, demasiadas libertades a la hora de hacer gestos o muecas. Es cierto que el buen actor sabría mostrar su tristeza y malhumor mediante la postura de su cuerpo y los movimientos de cabeza. Por lo demás, desde las palabras de presentación de la nodriza ${ }^{(102)}$, sabemos que la protagonista estaba con la cabeza baja, sin alzar la mirada y sin apartar del suelo su rostro ${ }^{(103)}$.

12. Creonte, en su diálogo con la heroína, muestra su miedo ${ }^{(104)}$ en repetidas ocasiones. Medea, es cierto, venía precedida de una terrible le-

y E. (13). En el primero, el Coro se lo atribuye a Orestes por haber matado a su madre (Eu. 607); más significativo para nosotros es $P$ r. 868 , donde el protagonista afirma que una de las hijas de Dánao (Hipermnestra), ablandada por el deseo, no le daría muerte a su compańero

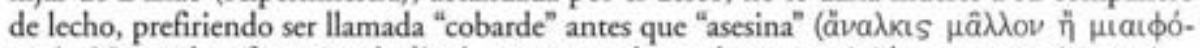

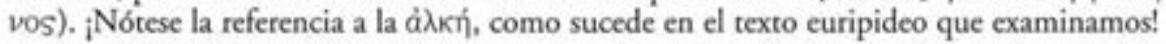

Eurípides acude con frecuencia a tal adjetivo, empleándolo incluso en comparativo, en el pasaje analizado, y superlativo (Tr. 881). (Hdt. (2) usa sólo el grado comparativo del término). Nuestro trágico aporta una innovación: el verbo correspondiente, $\mu$ taıфovétw (1).

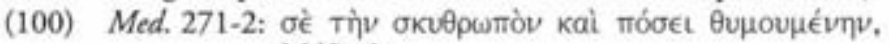

\section{Mñoet'...}

(101) Lo tenemos por primera vez en A., Ch. 738, aludiendo a Clitemnestra, que muestra un rostro sombrío ante los criados, mientras se ríe por dentro, cuando recibe la noticia de la muerte de Orestes. Este pasaje de la Orestia puede haber sido un precedente singular para nuestro poeta, buen conocedor e imitador de Esquilo en varias ocasiones. Lo relevante es presentarse con rostro sombrío mientras se piensa otra cosa por lo bajo.

Eurípides lo emplea ocho veces, $y$, además, aporta el verbo correspondiente en una ocasión. El adjetivo es usado cuatro veces por los médicos hipocráticos.

(102) Med. 24-8.

(103) En mi opinión, el pasaje podria entenderse mejor si aceptamos para tal adjetivo el sentido de "gruñón", "que maldice o murmura por lo bajo", basándonos en alguna glosa de

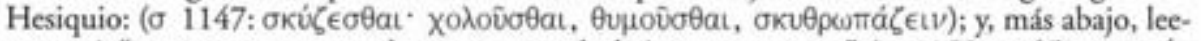

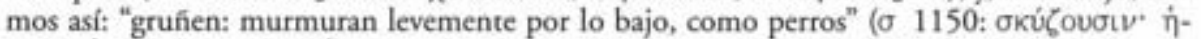

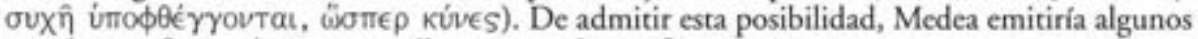
sonidos confusos, algún murmullo muestra de su aflicción. Estaríamos, pues, ante una sinestesia, pues el adjetivo empleado por Creonte habría que entenderlo aplicado a dos sentidos diferentes: la vista y el oído; lo que el espectador ve y, al mismo tiempo, oye.

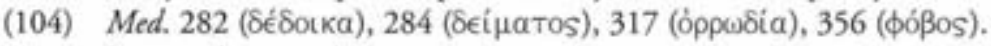

No puedo extenderme todo lo necesario en el examen de cada uno de estos términos. No obstante, diré lo esencial. 
yenda, y el rey de Corinto, reconociendo que es sabia ${ }^{(105)}$ por naturaleza y conocedora de muchas perfidias, no oculta sus temores por los actos que pudiera realizar.

13. La protagonista, recurriendo al llanto ${ }^{(106)}$ y a la adulación ${ }^{(107)}$, porque desea obtener ventaja ${ }^{(108)}$ o maquinar algo ${ }^{(109)}$, consigue que Creonte le dé un día más de estancia en Corinto:

Empezando por el tema $\delta \in \delta o t K-$, (presente en literatura griega desde f́bico, Anacreonte [1 aparición en cada uno] y Teognis [5]), lo conocen bien los tragediógrafos: A. (13), S. (14), E. (31: dos secuencias en $M e d$.).

Por su parte, en 284 no es necesaria la corrección del texto ( $\delta$ Ei $\gamma \mu a T a)$ aceptada por Dig-

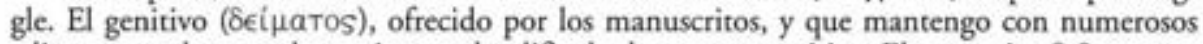
editores, puede entenderse, sin grandes dificultades, como partitivo. El sustantivo $\delta \in i ̄ \mu a$ aparece en Homero (1. Il. 5.682); lo recogen, entre otros, los trágicos: A. (11), S. (10), E. (17: dos ejemplos en la tragedia que revisamos).

Mayor interés para nuestro objetivo supone el sustantivo óp $\rho \omega \delta i ́ a$, ciertamente raro. Los etimólogos no se ponen de acuerdo acerca de su origen. Hesiquio (o 1320) lo explica como un sinónimo de фóßos, $y$ acude, precisamente, a Med. 317. En todo caso, no lo encontramos

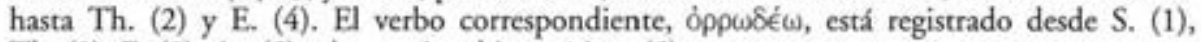
Th. (2), E. (3), Ar. (5) y los escritos hipocráticos (5).

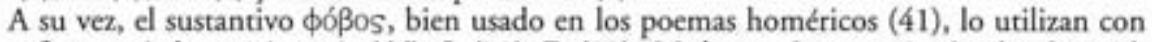
cierta frecuencia los trágicos: A. (44), S. (32), E. (98). Med, con 6 secuencias (184, 263, 356, $903,1202,1257)$, ocupa un lugar discreto, pues sobresalen Or. (14), Stupp. (8), y Heracl., HF y $\operatorname{Tr}$. (7 en cada una).

(105) Véase mi trabajo "Nueva lectura de sophia-sophós en la Medea de Eurípides", Eikasmós, 13, 2002, 41-61. No entraré, pues, en el muy interesante tema de la "sabiduría" y el "sabio" en esta obra.

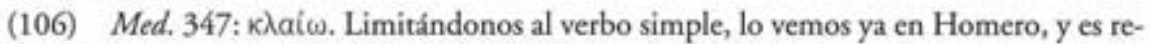
cogido, entre otros, por A. (12), S. (21) y E. (45). Sólo en dos ocasiones lo encontramos en Med. En primer lugar, en la secuencia que ahora vemos, donde la heroina no se emociona por lo que a ella se refiere, sino que llora por sus hijos al ver que estaban probando la desgracia (Todo es una argucia para despertar la compasión de Creonte). La segunda vez es Jasón quien emplea el verbo (v. 1377), cuando le pide a la infanticida que le permita llorar a sus hijos ya muertos. El lector puede darse cuenta de la moderación del trágico en el uso de tal verbo en una tragedia como la presente si establece una comparación con las secuencias que hallamos, por ejemplo, en Alc. (9). Eurípides es bastante parco en el empleo de dicho verbo.

(107) Med. 368: Outreûfal. Según Chantraine, es un verbo denominativo formado a partir de $\theta$ ćł $\psi-\theta \omega \pi$ Tós, "adulador": lo leemos, por primera vez, a partir de S. (3) y E. (2). Nuestro autor mostró singular agrado por tal familia de palabras, pues aportó innovaciones: los

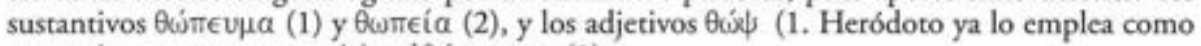

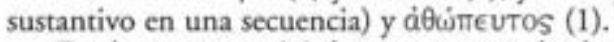

Es chocante que Medea, con un modo de ser tan duro y firme, se rebaje a elogiar a un enemigo: naturalmente, con una finalidad concreta, a saber, contar con las horas suficientes para llevar a cabo su venganza. Para que nadie dude de su carácter inflexible le cuenta al Coro por qué ha obrado de tal modo.

(108) El verbo Ke $\delta a i ́ v \omega$, "obtener ventaja", "sacar provecho", lo encontramos en griego a partir de Hes. (1: Op. 352); los trágicos lo emplean algunas veces: A. (2), S. (11), E. (13).

(109) Ya desde Hom. (Od. 11.613) contamos con teXuáoual, no con el sentido de "practicar un saber, oficio o arte" (cf. Od. 7.110), sino con el de "maquinar", "emplear astucias" 
...durante este día permitió

que me quedara, en el cual a tres de mis enemigos en cadáveres convertiré: al padre, a la hija y a mi esposo. ${ }^{(110)}$

14. Medea, una vez decidida a acabar con sus tres enemigos, no sabe bien de qué modo llevarlo a cabo, dudando entre el fuego o la espada ${ }^{(111)}$; finalmente, se resuelve a acudir a la vía directa en la que es sabia por naturaleza: aniquilarlos con venenos ${ }^{(112)}$. El contexto ofrece ciertas di-

en provecho propio. Entre los trágicos sólo lo usan S. (5) y nuestro autor (5); en éste el uso tiene algo de formulario, pues siempre aparece al final de verso y en participio: Med. 369, 382, 402; Herael. 1003 (Euristeo lo afirma refiriéndose a su propia persona); Hel. 1091 (Helena lo dice de sí misma).

$$
\text { Med. 373-5: }
$$

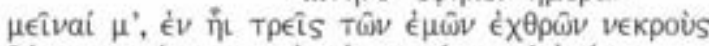

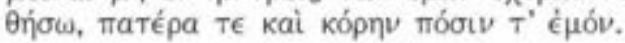

En esta secuencia (importante, entre otros motivos, porque es la primera vez que Medea considera "enemigos" tanto a su marido como a su nueva esposa y al padre de ésta) sólo me detendré en el sustantivo vekpoús, predicativo de los tres complementos directos citados en el verso siguiente. Para el público que óa esas palabras la intención de la heroína resultaba evidente; los tres morirán a manos de Medea. Hasta el final no se sabrá con certeza qué le sucederí a Jasón.

El sustantivo vekpós está bien registrado desde Homero (66); los trágicos lo emplean con frecuencia: A. (28), S. (35), E. (176). Nótese bien la predilección de nuestro autor por tal término. Med. (7) ocupa un lugar discreto, frente a Supp. (35), Ph. (27), Tr. (23), HF (14), etc.

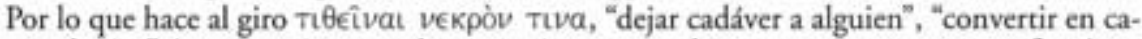
dáver a alguien" (construcción con dos acusativos: uno, objeto externo, y otro, que funciona como predicativo) contamos con un claro precedente en Esquilo: Ch. 575, donde Orestes le cuenta al Corifeo lo que piensa hacer en cuanto se encuentre con Egisto: "lo dejaré cadáver, envolviéndolo con mi bronce de pie ligero...".

Las intenciones de la protagonista resultan claras: acabar con sus tres enemigos. Si se secluye el v. 262 como una interpolación, sería la primera vez que su deseo queda expuesto de modo firme y decidido; de aceptar ese verso, tendriamos aquí la ratificación de lo que allí era sólo una aspiración, una posibilidad lejana. Ahora, tras la conversación con Creonte, Medea se resuelve a quitar la vida a los tres enemigos a que hace referencia: después vendrán las dudas sobre el modo y las consecuencias de lo que se dispone a hacer.

(111) En Andr. 841 ss., Hermione habla de cuatro posibilidades de acabar con la vida: atravesarse el hígado con la espada, ahorcarse, arrojarse desde un precipicio y prenderse fuego. En $H F 1148$ ss., Heracles expone una triple posibilidad (la estructura triádica la leemos también en otros autores), que coincide con la anterior, salvo en ahorcarse,

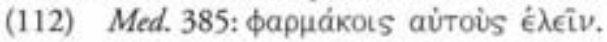

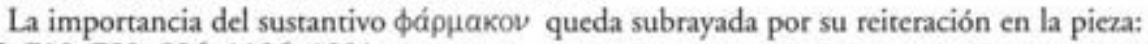
$385,718,789,806,1126,1201$.

Además, también en esta obra, famosa por los efectos letales de las drogas de Medea, tenemos un pasaje en que se apunta a los efectos beneficiosos de las mismas. Se trata del v. 718 , cuando la protagonista le promete a Egeo que logrará que deje estar sin hijos y conseguirá que siembre semilla de hijos. Es decir, sabria qué drogas solucionaban la esterilidad masculina. (Recordemos, Andr. 32, donde la protagonista habla de Hermíone, que piensa que permanece estéril por causa de las drogas de Andrómaca). En los demás casos, las drogas tienen 
ficultades, porque algunos entienden que la heroína está hablando de las mujeres en general, mientras que la opinión común es que se refiriere sólo a sí misma. En realidad, a la protagonista le venía de familia ${ }^{(113)}$ el conocimiento de las drogas, $y$, asimismo, el de su elaboración y propiedades.

\section{Medea invoca a Hécate:}

¡No, por la señora a quien venero más que a todas y por colaboradora la elegí, por Hécate, que habita en el interior de mi hogar: ninguno de ellos, contento, atormentará mi corazón! (114)

En este pasaje hay varios puntos que nos llaman la atención: a) "Venerar" a una divinidad; b) Elegirla como "colaboradora"; c) En tercer lugar, único aspecto en que me detendré, la mención de Hécate ${ }^{(115)}$, diosa de la he-

efectos letales al impregnar la diadema y el velo que envía como regalo a la recién casada, con efectos mortales sobre cualquiera que tocara a la víctima del veneno.

Dicho término es bien conocido desde Hom. (24), y lo recogen, entre otros, los trágicos: A. (12), S. (5), E. (35); es muy importante en los tratados hipocráticos (si contamos los pasajes en que aparece el tema фарцак- hay 644 secuencias), que contienen abundante material sobre fármacos empleados para remediar la esterilidad femenina; se piensa que, en muchos casos, se trata de remedios empíricos y mágicos procedentes de prácticas arcaicas, especialmente los ligados con la purificación (katharsis) de la paciente.

(113) Era nieta de Helio ("el que todo lo ve y todo lo sabe", desde los poemas homéricos) y sobrina de Circe - la que transformó con sus drogas en cerdos a los compañeros de Odiseoy de Pasifae, la que logró ayuntamiento bestial con el Toro de Creta. Es muy importante el trabajo de A. Moreau, "Médée bouc émissaire?", Médée et la violence..., en el que ha señalado los rasgos que definen a la heroína como "chivo expiatorio": ser extranjera, bárbara, maga y mujer.

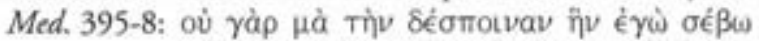

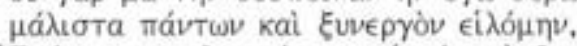

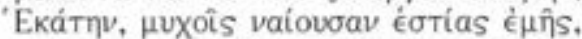

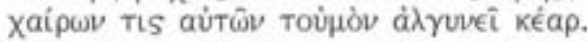

(115) Hesiodo es el primero en mencionarla, como hija de Perses y Asteria: Th. 411, 418, 441. Se nos dice en el poeta que Zeus la honró de modo singular, proporcionándole espléndidos regalos; es especialmente respetada por los dioses inmortales; incluso, en los días del autor épico-didáctico, algunos hombres la invocaban al celebrar magníficos sacrificios. La diosa puede ayudar y asistir a quien quiera; tiene muchos poderes sobre el juicio, el ágora, la guerra, e, incluso, aumenta, o disminuye, la pesca y el ganado. Como Ártemis-Hécate, protectora de los partos, la tenemos ya en A., Ch. 676; S. la ofrece en un fragmento (Fr. 535.2); E. la presenta como hija de Leto $(P h .110)$ y dos veces como "portadora de luz" (Hel. 569; Fr. 968.1). Un escolio a Med. 1172 nos indica que los antiguos atribuían a los dioses, especialmente a Pan y Hécate, los ataques momentáneos, síntomas de diversas enfermedades (Cf. Hipp.141 ss., donde también se menciona a Hécate junto a Pan, los Coribantes y la diosa madre, es decir, Cíbele).

La presencia de Hécate en las obras de Eurípides es discreta y limitada (seis apariciones); concretamente, en Medea sólo la encontramos en la secuencia que examinamos. Será a partir de Apolonio de Rodas (14) cuando la divinidad comience a ser muy relacionada con Medea y el mito de los Argonautas. Así sucederá, después, en los autores latinos. 
chicería y adivinación, cuyas estatuas — - según sabemos por varias fuentes-, dotadas de triple cuerpo, o cabeza, eran colocadas en las encrucijadas de los caminos. Para algunos es la madre de Medea ${ }^{(116)}$. En todo caso, es una divinidad ctónica, ligada a cultos relacionados con la muerte y el más allá.

16. Medea le ha contado sus propósitos al Corifeo: arruinar a Jasón de tal modo que ni pueda ver en el futuro a los hijos habidos con ella ni engendre descendiente alguno en la recién casada. Luego, añade:

¡Nadie floja ni débil me crea, ni indolente, mas de temperamento dispar!

Terrible para mis enemigos y con los amigos benévola.

Famosísima es la vida de tales seres. ${ }^{(117)}$

El léxico, una vez más, nos proporciona nuevos indicios sobre la personalidad de Medea. a) Ella misma afirma que no es "floja", recurriendo al adjetivo фaû̀os, ausente de los textos épicos, y que comienza a aparecer en los líricos del VI ${ }^{(118)}$, así como en la prosa del V ${ }^{(119)}$. Eurípides muestra indudable gusto por el término ${ }^{(120)}$. Aplicado a personas, tal adjetivo se utiliza de modo singular en la esfera del comportamiento ("incapaz, ineficaz, inhábil") o del carácter ("malo, malvado, vil"); b) Tampoco es "débil" (121), ni indolente ${ }^{(122)}$; c) La presencia de трómos ${ }^{(123)}$ nos indica que la heroína se está refiriendo a su modo de ser, a su comporta-

(116) Cf. Epimenid., Fr. 11.3. Por su lado, Diodoro de Sicilia (4.45.1-3), siguiendo ideas de Dionisio Escitobraquión, la tiene, en cambio, por esposa de Eetes y madre de Circe y Medea.

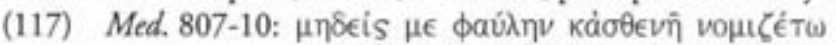

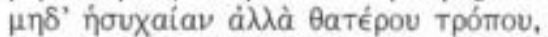

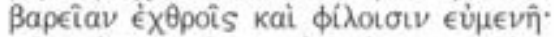

(118) Mimn. (1).

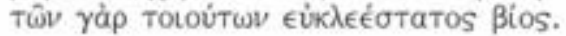

(119) Hdt. (1), Th. (8), etc. Luego, lo emplean con cierta frecuencia los escritos médicos y Platón.

(120) E. (22). De los otros trágicos sólo lo utiliza S. (2).

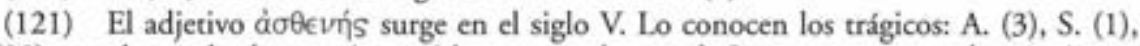

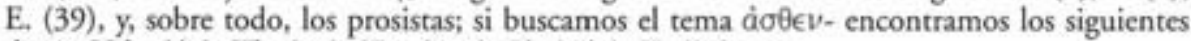
datos: Hdt. (47), Th. (77), Hp. (332), Pl. (147), X. (90), etc.

(122) Aplicado al comportamiento, ñouxaîos es bastante raro. Lo leemos en A., Eu. 223, atribuido al modo de ser de las Erinis.; S. sólo lo registra en un fragmento (Fr. 941.6); E, lo emplea tres veces.

(123) El sustantivo no lo tenemos en Homero (si el adjetivo troגútpotros, por ejemplo). Lo leemos, en cambio, en Arquíloco, Safo, Semónides, Teognis, Píndaro; etc. ; también en los trágicos: A. (42), S. (19), E. (60). En general, puede afirmarse que, cuando se refiere a personas, tal vocablo tiene el valor de "modo de ser, conducta, hábito". Con tal sentido, Jenofonte ofrece numerosos textos de notable interés. 
miento; d) No me detendré en el v. 809 donde se establece con toda claridad la oposición enemigo/amigo ${ }^{(124)}$, así como la diferente actitud de la protagonista frente a cada uno de ellos; e) Finalmente cabe señalar el adjetivo "muy famosa" (125) atribuido a "la vida", "tipo de vida".

17. En la segunda escena en que, frente a frente, intervienen Jasón y Medea, ésta le pide perdón e incluso elogia sus intenciones al contraer nuevo matrimonio; afirma que se encuentra propensa al llanto, llena de terror y con sus tiernos ojos repletos de lágrimas. En ese contexto se expresa con estas palabras:

Una mujer, femenil es, por natura, y propensa a lágrimas ${ }^{(126)}$.

(124) Véanse otros ejemplos paralelos de la norma moral griega, en el periodo arcaico y clásico, de odiar al enemigo y amar al amigo: Archil., 23.14-15; Sol., 13.5-6; Thgn., 869-72; E., Io. 1046; HF 585; etc.

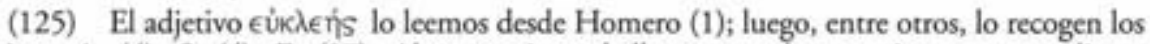
trágicos: A. (4), S. (4), E. (27). Algo semejante hallamos en el sustantivo correspondiente $\epsilon u ̈ \kappa \lambda \epsilon \iota a$ : Hom. (4), A. (7), S. (6), E. (18). Nuestro poeta sigue la línea iniciada por Esquilo, según la cual ser "famoso" pasa también al campo femenino. Así lo vemos en A., Supp. 975, referido a las Danaides. Algo semejante tenemos en S., El. 973, donde la protagonista apunta a la condición de famosa de su hermana Crisótemis en caso de que obrara como ella le aconseja.

Eurípides da un paso adelante en la atribución de la condición de "famosa" a la vida, "forma de vida", de quienes obran de cierto modo; en este caso, a pesar de la indiferencia de género de Totoútwi, todo apunta al campo femenino, y las palabras están pronunciadas por una mujer. Ya en Alc. 623 tenemos el adjetivo referido a ßios, cuando se nos dice respecto a la pro-

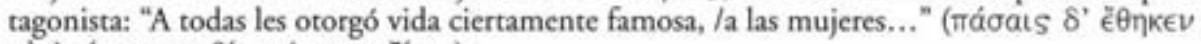

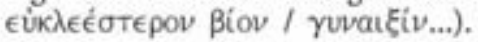

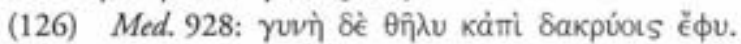

Si hacemos un rastreo del tema yov- tenemos: Hom. (268), A. (138), S. (129), E. (627). Dentro de nuestro autor, el uso de dicho tema, contando sólo las tres primeras piezas ordenadas de mayor a menor: Alc. (63), Andr. (58), Med. (52); si nos limitamos al empleo del nominativo $\gamma u v \eta$, vemos lo siguiente: Alc. (18), Med. c Hipp. (9 cada una), etc. Nuestra pieza, pues, destaca por la presencia de tal sustantivo.

Según los datos del TLG, el tema $\theta \eta \lambda$ - lo registran, entre otros, Hom. (24), A. (22), S. (7), E. (50). Importante es S., Tr. 1062-3, donde Heracles, el gran héroe de los griegos, exclama: "Una mujer, siendo femenil, no con naturaleza propia de varón, / ella sola me derrotó sin espada":

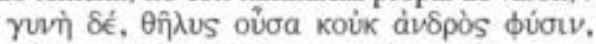

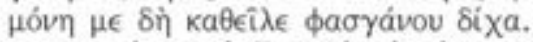

Concretamente, dentro de Eurípides, las dos tragedias que ofrecen más usos de $\theta \bar{T} \lambda$ us son $B a$. (6) y Med. (3). En nuestra pieza el adjetivo sirve para referirse a todo el sexo femenino, por oposición al masculino, en boca de Jasón ( 574 , donde manifiesta su deseo de que los hombres engendren hijos de algún modo distinto y que no exista el linaje femenino; y 909 , con la idea de que es natural que el sexo femenino se encolerice contra el esposo si éste contrae nuevo matrimonio), y como algo "débil", "flojo", "blando" (en otros contextos tiene el matiz de "afeminado") en el ejemplo que nos ocupa ahora, pronunciado por la heroína. Sintácticamente, en el pasaje que revisamos, $\theta \hat{\eta} \lambda v$ es neutro y, por el contexto, debe entenderse con un cierto matiz despectivo, peyorativo, según notan los estudiosos. (Tanto ese adjetivo como el sustantivo $\theta \eta \lambda \hat{n}$ proceden de la raiz indoeuropea que significa "mamar", "chupar"). 
18. Las lágrimas han causado el efecto deseado sobre Jasón: a saber, que, tras perdonar a Medea por sus terribles palabras - entre otras cosas le había dicho que se marchara de prisa al palacio pues, al demorarse, era presa de deseo hacia la muchacha recién casada ${ }^{(127)}$ —; además, le había criticado por su nuevo matrimonio, diciéndole que se arrepentiría de élmantenga lo que en un momento anterior propusiera: que sus hijos se queden seguros en Corinto.

Ahora bien, Jasón carece de capacidad para tomar decisiones de ese tipo; hay que convencer a la joven esposa para que, a través de su padre, se les otorgue a los niños, en la ciudad, la seguridad y protección debidas. Es un punto

Además, la protagonista recurre a un giro sintáctico repetido varias veces en nuestro poeta, a saber, étri con dativo, con un matiz temporal-local indefinido, de duración permanente. Se insiste con ello en la propensión de la mujer a las lágrimas. Con respecto al tema $\delta a \kappa p v-$ véase nota 29.

Medea dice de sí misma (v. 903) que es áptíðakpus, innovación euripidea de escaso uso

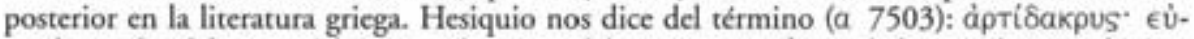

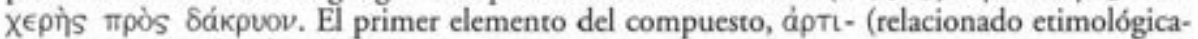

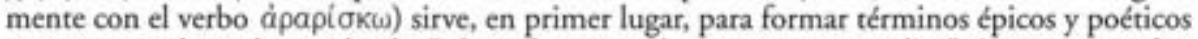
en que prevalece el sentido de "adaptado, ajustado, propenso, proclive" (piénsese en à $\rho$ $T \in \epsilon \pi$ S, "propenso a la palabra"); pero, ya desde el siglo V, contamos con otros derivados en que aparece una precisión temporal como valor usual, "recientemente", "inmediatamente", "en seguida". Chantraine explica el compuesto que estamos revisando como "el que acaba de llorar o que va a llorar", es decir, con una connotación temporal.

Las lágrimas son esenciales en el comportamiento de Medea, pues, gracias a ellas, engañará a Jasón convenciéndolo de que acepte que sus hijos le lleven regalos a su nueva esposa; de ese modo, la protagonista conseguirá llevar a cabo su venganza. Esas lágrimas, pues, no son las de un ser normal, sino las de una maga, sabia y astuta, conocedora de todas las claves de la psicologia humana, y sabedora, por tanto, de las emociones que las lágrimas pueden despertar; por ello, Medea merece el epiteto especial, rebuscado, que le atribuye nuestro trágico.

En Medea, no obstante, no abundan las lágrimas, circunscritas a la protagonista (nos lo dice la nodriza: 25; el Corifeo: 905; Jasón: 922; el pedagogo: 1012; el Coro se pregunta, por su parte, cómo podrá realizar sin lágrimas el destino mortal de sus hijos - 861: Tékvots ăઠa-

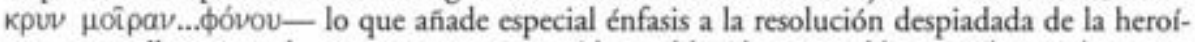
na, que no llorará en el momento supremo, ni le temblará la mano al levantar la espada contra sus hijos. Por cierto, ắakpus, en el periodo clásico, sólo lo registramos una vez en Píndaro y dos en nuestro autor; luego lo tenemos en Teócrito, Plutarco, etc.), o al mensajero (1221). Jasón no llora en ningún momento, aunque algunos pasajes indican que está dispuesto a llorar

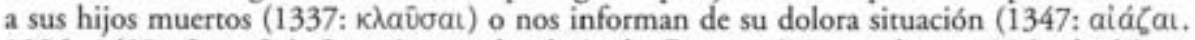

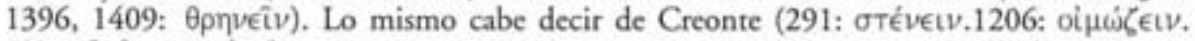

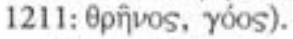

(En cambio, el lector interesado podrá saber de las abundantes lágrimas de Agamenón en LA: 40, 398, 477, 496, 541, 650, 1550).

(127) Med. 623-6. Tales palabras tienen un indudable sentido sexual: la pasión desbordada propia de los recién casados. Por otra parte varios términos del campo semántico del matrimonio y la relación sexual subrayan el pasaje. Además, late en esos versos una verdadera provocación de la heroína —está sola, pero, con todo, puede exponer sus argumentos - a Jasón, que tiene el tiempo contado, escaso, y se ve atado por su nuevo enlace. 
esencial para la muy astuta Medea, sabedora como nadie de los resortes últimos de la voluntad humana. Si hasta ahora ha actuado por la vía de la piedad y lástima, ahora lo hará por el camino de los magníficos regalos, que despiertan la vanidad y el amor a las riquezas; pero para que sus hijos lleven a palacio los letales dones es necesaria la aprobación de Jasón. Éste, no obstante, picado en su amor propio piensa que no es necesario regalarle nada a su joven esposa, pues está seguro de que ella lo preferirá a él antes que a las riquezas.

En ese momento, la heroína se expresa de este modo:

¡No me lo hagas! Que regalos convencen incluso a dioses es fama. El oro más fuerte que infinitas palabras resulta para los mortales. ${ }^{(128)}$

El proverbio del primer verso remonta a Hesíodo ${ }^{(129)}$. Por lo demás, la importancia del oro en las obras euripideas es conscipua, si la comparamos con los precedentes literarios más sobresalientes ${ }^{(130)}$. Nuestro trágico, excelente conocedor de los poderes de la palabra, subraya, la extraordinaria fuerza del oro para los mortales ${ }^{(131)}$. Así consigue un paralelo con respecto al verso precedente: los regalos son para los dioses ${ }^{(132)}$ lo que el oro para los hombres ${ }^{(133)}$.

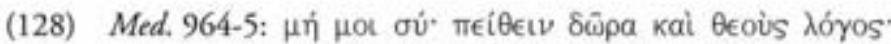

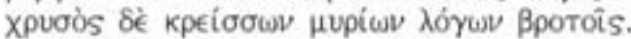

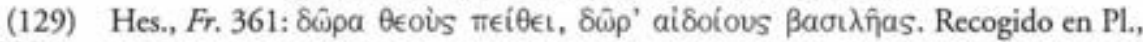
R. $390 \mathrm{e}$.

Los dioses hacen regalos a los hombres (la construcción típica es con el nombre del dios en genitivo subjetivo) desde los poemas homéricos. Paulatinamente, en cambio, vemos que los hombres ofrecen regalos a los dioses, para atraerse sus favores: Cf. Anacr. Epigr. 139.1: (Praxágoras dedicó dones a los dioses), A., Fr. 161.1 (donde Tánato es el único entre los dioses que no ama los regalos), Pi., Fr. 119.1 (los antepasados de Terón ofrecieron muchísimos presentes a los inmortales), etc.

De otra parte, a partir de Alcmán y Estesícoro encontramos el nominativo de singular $\lambda o ́-$

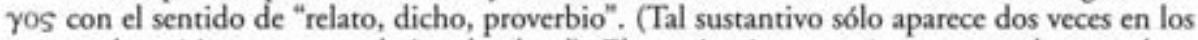
poemas homéricos, pero en dativo de plural). El nominativo, con ése y otros valores, es bastante utilizado por los trágicos (A., 24; S., 23; E., 63).

(130) Examinado el tema X $\rho$ u-, tenemos: Hom. (238, una vez descontados varios nombres propios), A. (38), S. (31), E. (185). Dentro de las obras euripideas el orden de las tres primeras según la frecuencia de tal tema es: Hec. (22), Io. (21), Med. (16).

(131) Cf. E., Fr. 325: Superior a las riquezas no ha nacido ningún hombre, salvo si existe uno: quién sea ése, no lo veo.

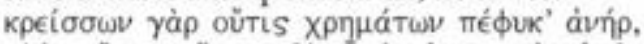

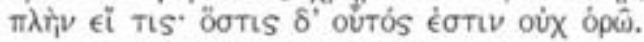

(132) Siguiendo una lectura total del TLG, en Eurípides se encuentran casi 700 usos del tema $\theta \in 0-($ A., 280; S., 207). Med. ocupa un lugar intermedio con 25 apariciones (la más rica es $I o$. con 78).

(133) La distinción dios/mortal, bien establecida desde Homero (como se sabe, Bpotós, "mortal", procede de la raíz indoeuropea "mer-, origen también del latino mortuus. Los 
19. Medea, cuando sus hijos habían vuelto tras llevar los letales dones a la recién casada, les pide la mano para besársela, les desea que sean dichosos, pero en el otro mundo, los abraza, siente su delicada piel y aliento dulcísimo; no es capaz, ya, de dirigirles la mirada, vencida por las desdichas. En tal momento exclama:

\author{
Comprendo qué crímenes voy a cometer; \\ mas mi ira más fuerte resulta que mis razones; \\ culpable es de grandísimas desgracias para los mortales. ${ }^{(134)}$
}

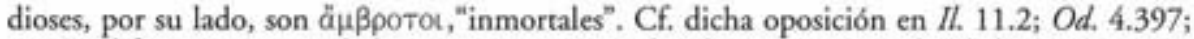
etc. La diferencia, aparte de la muerte que separa los dos grupos con claridad, consiste también en las diferentes comidas y bebidas: acúdase a $\mathrm{Od}$. 5.197, a propósito de Calipso y Odiseo), resulta clara en pasajes como éste (Otros lugares de nuestro poeta en que se advierte la oposición referida pueden hallarse en Cyc. 285, 605; Hipp. 120; etc.). De los los numerosos ejemplos euripideos de ßpotós, Medea es la primera en usos aportados (19, junto con Hipólito). La protagonista se siente especial: se sabe "diferente de muchos mortales en muchas co-

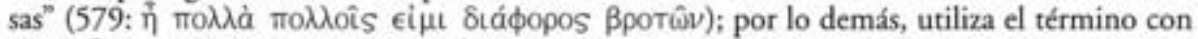
cierta frecuencia: $330,573,579,965,1080$.

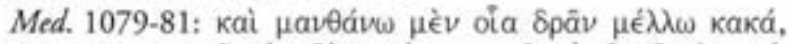

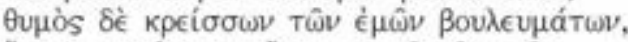

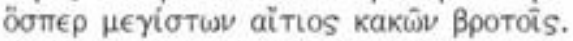

Aristófanes, que tantas veces imita a nuestro trágico, parodia el monólogo de la heroína en Pax 1013-15.

Por lo demás, la figura de Medea despertó la atención de los estudiosos de época helenística e imperial (El TLG recoge casi 400 veces tal nombre desde el siglo $\mathrm{V}$ a.C. hasta el II d.C.; están incluidas las numerosas obras perdidas tituladas asi, indicio de que el personaje siguió gustando en la posteridad. No menos de trece dramaturgos, trígicos o cómicos, escribieron en ese periodo Medeas de las no nos queda casi nada). En concreto, el pasaje mencionado fue citado, estudiado y comentado, por Crisipo, Epicteto, Galeno, Clemente de Alejandría, Albino, etc. Galeno se ocupó en once ocasiones del personaje mítico. Nos interesa, de modo relevante, el texto en que, criticando duramente a Crisipo (éste recoge los vv. 1079-80 - Cf. Fr. 473.61 - y, además, comenta unos versos homéricos $(\mathrm{Od} .20 .5-22)$ a propósito de Odiseo y el Ciclope), afirma: "en el alma de la heroína, la razón pugnaba con la ira, pues sabía qué impío y terrible acto cometería poniendo mano a la muerte de sus hijos, y por eso vacilaba y se demoraba, y no cometió la acción lanzándose a ella al instante. Pero, de nuevo, su ira, como un caballo desobediente vence al auriga, se deslizó contra sus hijos con violencia. Y, después, otra vez, la razón la rechazaba y apartaba, y, luego, de nuevo, la ira la arrastraba en sentido contrario; y, otra vez, la razón. De manera que, tras ser llevada arriba y abajo por ambos, como cediera a la ira, entonces la presenta Eurípides diciendo: "Y comprendo qué males voy a cometer; I mas la ira, más fuerte resulta que mis razones". Comprende ya la magnitud de los males que va a cometer, informada por la razón, pero afirma que más fuerte que ésta es la ira, $y$, por eso, por obra de aquélla es llevada violentamente a la acción; al contrario de Odiseo, que con la razón contenía su ira. Pues puso Eurípides a Medea como ejemplo de hombres bárbaros y sin educación, entre los cuales la ira es más fuerte que la razón. Pero entre helenos y hombres cultivados, como, a su vez, presentó el poeta (sc. Homero) a Odiseo, la razón es más fuerte que la ira. Muchas veces la razón es más fuerte que la parte irascible del alma hasta tal punto que jamás acontece batalla de una con la otra, sino que una domina y la otra es dominada. $Y$ eso les ocurre a quienes llegan al final de la filosofia. Pero muchas veces la ira vence a la razón hasta tal 
Esta secuencia ha interesado a filólogos y filósofos. Mastronarde recoge lo esencial en un apéndice esclarecedor. Por mi parte, sólo entraré en algunos detalles léxicos.

punto que la domina y la conduce por completo. En muchos de los bárbaros se ve eso, y, entre los niños, en los iracundos, y en no pocas de las fieras, $y$, de entre los hombres, en los feroces. Hay ocasiones en que ninguna de las dos es más fuerte de tal manera que la otra sea arrastrada al instante, sino que se oponen entre sí y combaten, $y$, con el tiempo, vence una de las dos; en Odiseo, la razón; en Medea, la ira; las dos son partes del alma, o, si no partes, ciertas facultades, sin duda. Pero Crisipo, sin pensar que ésas son partes del alma, ni que existen facultades irracionales distintas de la racional, no vacila, sin embargo, en mencionar los versos de Odiseo y de Medea, que echan por tierra, evidentemente, su opinión" (5.306.9308.12).

Pero digamos algo de los versos euripideos que hemos recogido. En primer lugar, $\mu a v-$ Өávw, "sé bien", "comprendo" —en el contenido verbal es esencial el saber acumulado mediante la experiencia; en este caso la heroína conoce bien cómo es su modo de ser-, en primera persona. El verbo, en el tema de aoristo, es normal desde Homero, pero sólo en el siglo $\mathrm{V}$ es usado en el tema de presente. Además, la primera persona del presente de indicativo en una novedad aportada por Sófocles (6) y Eurípides (6). Nuestro poeta sólo lo había usado una vez (Alc. 940), cuando el muy egoísta Admeto "comprende" lo que le espera tras la muerte de su esposa. Aristófanes (13) y Platón el cómico (2) también registran esa forma verbal, muy corriente luego en Platón (84).

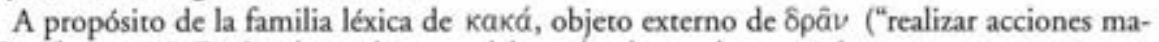

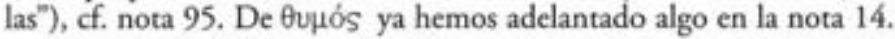

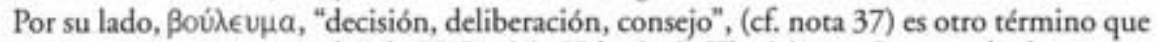
aparece por primera vez en el siglo V: Pi. (3), Hdt. (11), Th. (3), etc. La tragedia lo conoce bien y, con Esquilo, es la primera en usarlo: A. (9), S. (11), E. (41). Dentro de nuestro tragediógrafo, Med, ocupa un lugar de excepción por el número de secuencias ofrecidas (9), seguida de Hipp. (5) y Hec. (4). Med. lo recoge en 270, 372, 449, 769, 772, 886, 1044, 1048, 1079. (Los subrayados los pronuncia la protagonista y alude a su propia persona, salvo 886, donde apunta a Jasón). Los tres últimos lugares corresponden al monólogo de la heroína, que en 1044 decide no matar a sus hijos, renunciando a sus deliberaciones anteriores; repite la frase cuatro versos más abajo, para apoyar su cambio de planes (sacar a sus hijos del país), pero finalmente se decidirá al terrible crimen.

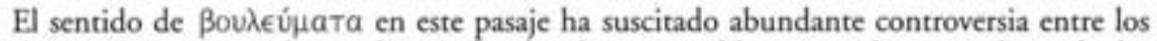
estudiosos. Creo que en el monólogo indicado, el poeta establece repetidamente, de modo deliberado, un contraste entre el corazón como órgano físico y asiento de la ira (vv. 1042-1052-

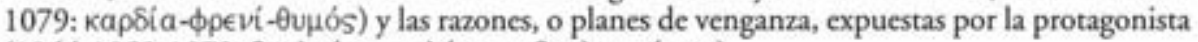

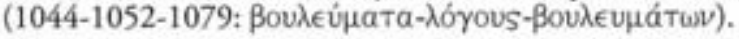

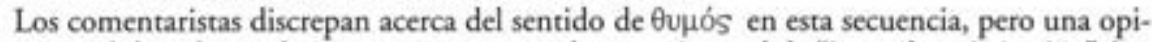
nión extendida es la que lo interpreta con un valor semejante al de "ira, cólera, irritación" (representada en griego, entre otros vocablos, por ópyí), significado presente ya en Homero

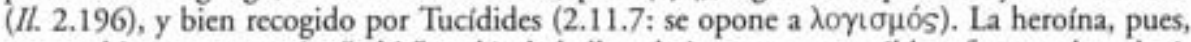
conoce bien, como mujer "sabia", a dónde la lleva la ira, a cuyos terribles efectos sobre el género humano hace referencia de modo sumario (Para otros pasajes en la misma línea de pen-

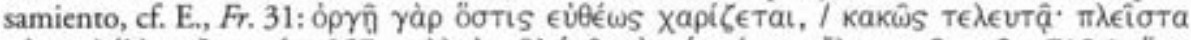

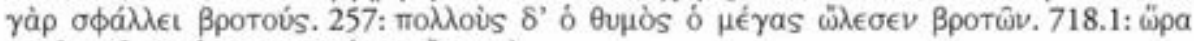

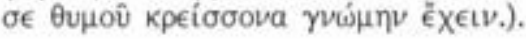




\section{BIBLIOGRAFIA SELECTA}

BLUNDELL, M.W.: Helping friends and harming enemies.A study in Sophocles and Greek ethics, Cambridge, 1989.

BURNETT, A.P.: "Medea and the tragedy of revenge", $C P h 58,1973,1-24$.

CaiazzA, A.: "Medea: fortuna di un mito", Dioniso 59, 1989, 9-84; 60, 1990, 82-118; 63, 1993, 121-141; 64, 1994, 155-166.

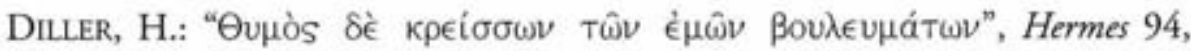
$1966,267-275$.

DUNKLE, J.R.: "The Aegeus episode and the theme of Euripides' Medea", TAPhA $100,1969,97-107$.

EASTERLING, P.E.: “The infanticide in Euripides' Medea", YCIS 25, 1977, 177 191.

Ebener, D.: "Zum Motiv des Kindermordes in der Medeia", RhM 104, 1961, 213-224.

ErbSE, H.: "Medeias Abschied von ihren Kindern (zu Eur. Med. 1078-1080)", Hermes 120, 1992, 26-43.

EurIPIDES: Medea, introd., ed., com., D.L. Page, Oxford, 1967(19381).

- Medea, introd., ed., com., D.J. Mastronarde, Cambridge, 2002.

FriedriCH, W.H.: "Medeas Rache", NAWG 4, 1960, 4, 67-111.

FrITZ, K. von: "Die Entwicklung der Iason-Medea-Sage und die Medea des Euripides", AC̛A 8,1959, 33-106.

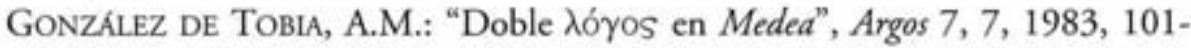
112.

KNox, B.M.W.: "The Medea of Euripides", YCLS 25, 1977, 193-225.

LOPEZ FÉrEZ, J.A.: "Sophia- sophós dans la Médée d'Euripide", en Médée et la violence..., 139-151.

- "Nueva lectura de sophia-sophós en la Medea de Eurípides", en Eikasmós, 13, 2002, 41-61.

- "Mitos en las obras conservadas de Eurípides", en Mitos en la literatura griega arcaica y clásica, J.A. López Férez (ed.), Madrid, 2000, 231-386 (especialmente, 242-249).

Kovacs, D.: "On Medea's great monologue (E. Med. 1021-80)", CQ 36, 1986, 343-352.

- "Zeus in Euripides' Medea", AJPh 114, 1993, 45-70.

MaddalenA, A.: "La Medea di Euripide", RFIC 41, 1963, 129-152.

MEDEA: Essays on Medea in Myth, Literature, Philosophy and Art, J.J. ClaussS.I. Johnston (ed.), Princeton Univ. Press, 1997. 
MEDEAS: Versiones de un mito desde Grecia hasta hoy, A. López-A. Pocińa (ed.), III, Universidad de Granada, 2003.

MÉDEE ET LA VIOLENCE: (Colloque international organisé à l'université de Toulouse-le Mirail, 28-30 mars, 1996). Pallas, 45, 1996.

MiL..S, S.P.: Euripides' Medea. A study in dramatic mythopoeia, (tesis), Stanford Univ., 1976.

Moreau, A.: Le mythe de Jason et Médée. Le va-nu-pied et la sorcière, Paris, 1994.

NÁpoLI, J. T.: "El discurso de la nodriza en el prólogo de Medea de Eurípides y la cuestión del amor", Synthesis 10, 2003, 55-75.

Prato, G.: "La Medea di Euripide e la dikè d'Afrodite", AFLL 5, 1969-1971, 37 51.

Pucc1, P.: The violence of pity in Euripides' Medea, Ithaca, 1980.

Schein, S. L.: "Philia in Euripides' Medea", en M. Griffith-D.J. Mastronarde (ed.), Cabinet of the Muses (Festschrift T.G. Rosenmeyer), Atlanta, 1990, 5773.

SChlesinger, E.: “Zu Euripides' Medea”, Hermes 94, 1966, 26-53.

SEGAL, Ch.: "Euripides' Medea: Vengeance, Reversal and Closure", Médée et la violence..., $15-44$.

SeIDENSTICKER, B.: "Euripides, Medea 1056-1080", en M. Griffith-D.J. Mastronarde (ed.), Cabinet of the muses. Essays on classical and comparative literature in honor of Th.G. Rosenmeyer, Atlanta, 1990, 89-102.

Stanton, G. R.: "The end of Medea's monologue: Euripides, Medea 10781080", RhM 130, 1987, 97-106.

TARDITI, G.: "Euripide e il drama di Medea", RFIC 35, 1957, 354-371. 